\title{
Board Composition, Family Ownership, Institutional Distance and the Foreign Equity Ownership Strategies of Turkish MNEs
}

\author{
by
Tulay Ilhan-Nas ${ }^{1}$, Tarhan Okan ${ }^{2}$, Ekrem Tatoglu ${ }^{3}$, Mehmet Demirbag ${ }^{4 \#}$, Geoffrey Wood $^{5}$, Keith W. Glaister ${ }^{6}$

${ }^{1}$ Professor of Management and Organization, Department of Business Administration, Faculty of Economics and Administrative Sciences, Karadeniz Technical University, Trabzon, 61080, Turkey. E-mail: tulayco@ktu.edu.tr

${ }^{2}$ Associate Professor of Management and Organization, Department of Management Information Systems, Faculty of Applied Scienes, Bandirma Onyedi Eylul University, Merkez Yerleşkesi, Bandirma, 10200, Turkey. E-mail: tokan@bandirma.edu.tr

${ }^{3}$ Professor of International Business, School of Business, Ibn Haldun University, Basaksehir, Istanbul, 34494, Turkey. Email: ekrem.tatoglu@ihu.edu.tr

${ }^{4}$ Professor of International Business, Deputy Dean, Essex Business School, University of Essex, Elmer Approach, Southend-On-Sea, SS1 1LW, United Kingdom. E-mail: mdemirc@essex.ac.uk

${ }^{5}$ Professor of International Business, Dean, Essex Business School, University of Essex, Wivenhoe Park, Colchester CO4 3SQ, United Kingdom. E-mail: gtwood@essex.ac.uk

${ }^{6}$ Professor of International Business, Leeds University Business School, Centre for International Business at the University of Leeds (CIBUL) 10-12 Cromer Terrace, Leeds, United Kingdom. E-mail: k.w.glaister@leeds.ac.uk

\section{\#Corresponding author}




\title{
Board Composition, Family Ownership, Institutional Distance and the Foreign Equity Ownership Strategies of MNEs
}

\begin{abstract}
In much of the developing world, families represent the dominant form of firm ownership. This study investigates how this influences equity ownership strategies when firms venture abroad. Drawing on agency theory and institutional theory, we investigate the direct effect of board composition and family ownership on the equity-based ownership strategies of multinational enterprises (MNEs) in their affiliates, and how institutional distance may moderate this. Examining foreign affiliates of listed Turkish MNEs, we find that a high ratio of independent directors is negatively linked to levels of equity ownership of MNE affiliates. We also find that a high ratio of inside directors on the board is positively associated with the equity stake of MNEs in their affiliates. The significant interaction effect between board composition, family ownership and institutional distance helps explain the unexpectedly weak effects of institutional distance.
\end{abstract}

Keywords: Board composition, foreign equity ownership strategy, family business, agency theory, institutions, Turkey. 


\section{Board Composition, Family Ownership, Institutional Distance and the Foreign Equity Ownership Strategies of MNEs}

\section{Introduction}

How do families impact the internationalization activities of firms in which they hold a significant stake? This study investigates the effects of board composition and family ownership on the equity ownership strategies of multinational enterprises from emerging markets (EM MNEs) in their affiliates. Further, we assess the moderating effect of institutional distance on this relationship. MNEs may be subject to pressures from a range of different institutional regimes, reflecting both investor country of origin and where the foreign operations take place. There is an extensive literature on how MNEs behave abroad (Almond et al., 2005; Brewster et al., 2008), which has tended to concentrate on the relative infusion of policies and practices from the country of origin. Less attention has been accorded to the association between the MNE's internal corporate governance mechanisms and foreign equity ownership (e.g. Rhoades \& Rechner, 2001; Filatotchev et al., 2007; Musteen et al., 2009; Filatotchev \& Wright, 2011). Internal corporate governance reflects both institutions, and the strategies dominant owner interests adopt in response to them. When formal regulation is weak or uncertain, the nature of the latter is vested with particular importance. Whilst weaker institutional coverage may be associated with greater agency problems (La Porta et al. 2000a), this does not preclude actors from improvising solutions that secure the best returns possible under the circumstances (Lane \& Wood 2012). Within an emerging market (EM) context, we explore how international investment strategies may be molded by corporate governance realities and dominant ownership forms. This study makes extensive use of recent advances in institutional theory and develops insights into the implications of family capitalism for key players. It further evaluates how internal corporate governance mechanisms intersect with external ones in imposing a specific agenda on the firm.

We combine two key theoretical perspectives in international business research: agency theory and institutional theory. Agency theory signifies a challenge to the traditional Chandlerian notion of the firm and recasts it as primarily a vehicle for releasing value to the 
owners. Hence, it favors external and internal corporate governance arrangements that support owner primacy and mechanisms for aligning managerial decision-making that maximizes short-term returns (Jensen \& Meckling, 1976). In line with agency theory, it may be argued that board composition is a major factor in the strategic planning process of MNEs, by affecting their risk perception and approach towards internationalization (Filatotchev \& Wright, 2011). Consequently, board composition is likely to be a crucial precursor of managerial skill to engage in internationalization strategies (Carpenter \& Fredrickson, 2001; Filatotchev et al., 2007; Filatotchev et al., 2008). However, how boards are composed is likely to be closely bound up with the institutional setting.

Agency theory and institutional theory have appeared as important approaches to explain foreign entry strategies of MNEs. Gaur and Delios (2015) argue that institutional arrangements impact both on external and internal corporate governance arrangements. Building on the tradition of North (1987), Gaur and Delios (2015) cast institutions as providers of incentives or disincentives for rational actors, encouraging optimal or suboptimal paths of decision making, which can be understood in agency terms. They conclude that both ownership concentration and ownership identity mold performance. Those strands of institutional theory that see private property rights as the most important regulatory feature share the basic concerns of agency theory surrounding the need to reign in managers and prioritize the release of shareholder value (La Porta et al., 2000a), enabling syntheses between these two traditions (Gaur \& Delios, 2015). From an integrated perspective, it can be assumed that risk preferences and other interests of decision-makers, such as board members, are shaped by institutional distinctions between home and host countries. Consequently, the predicted effects of board composition on the entry mode choices of MNEs are determined somewhat by institutional distance. Apart from the separate effects of board composition and institutional distance on entry strategies, we also investigate whether the institutional distance between home and host countries has a moderator effect on the relationship between board composition and MNE entry strategy. However, it could be argued that the relationship between institutions and structures is a two way one, and that actors will undertake actions that not only respond to, but in many instances bypass or seek to remold those institutional 
arrangements not to their liking (Lane \& Wood, 2009). The latter forms a central concern of this paper.

We focus on an EM setting, given that in such contexts institutions are less closely coupled or aligned, which might provide more opportunities for norm entrepreneurs to challenge and reform existing ways of doing things (Dore, 2008). At the same time, institutional shortfalls may make agency issues much more visible (La Porta et al., 2000a). In many EMs, the legal system is less predictable and/or effective and the market for corporate control less developed, with family owned and controlled firms the dominant ownership form (Amsden \& Hikino, 1994; Claessens et al., 1999; Guillén, 2000; Demirbag \& Yaprak, 2015). Boards of directors that contain family members, rather than independent members, may have a greater effect on the firm's strategic decisions (Demirbag et al., 1995; Selekler-Goksen \& Yildırım-Oktem, 2009). In the absence of other external mechanisms to protect minority shareholders (Kula \& Tatoglu, 2006), owner families have viewed the board of directors simply as a vehicle to maintain control over their firms (Selekler-Goksen \& Yıldırım-Oktem, 2009). As Gaur et al. (2014) note, firms rely on networks to overcome the consequences of institutional voids, in other words, relying on informal ties to get things done when formal modes of regulation are unsupportive or capricious. Internal corporate governance represents not only a mechanism for building on systemic strengths but also for compensating for weaknesses (Singh et al., 2013; Lane \& Wood, 2012). This may make family ownership a relatively efficient mode of control (Fainschmidt et al., 2016), irrespective of the problems it might open up for minority investors.

A burgeoning body of literature deploys institutional theory to understand the strategic choices of EM MNEs (Peng, 2003; Wright et al., 2005; Demirbag et al., 2010a; Surdu \& Mellahi, 2016; Peng et al., 2008; Wood \& Demirbag, 2012). North (1990, p. 3) states that institutions are normally described as the "rules of the game in a society" which consist of formal rules and informal constraints. Institutional theory suggests that the success and survival of an MNE hinges on its compliance with the rules and belief systems prevailing in business environments (Deephouse, 1996; Xu \& Shenkar, 2002; Dacin et al., 2007). The 
decisions of MNEs may be influenced in very diverse ways by the institutional distance between home and host countries (Campbell et al., 2012).

The remainder of the study is organized as follows. The next section reviews the relevant literature and sets out the study's hypotheses. We then present the research methods, followed by data analysis and results. The final section contains a discussion and conclusions.

\section{Context, theory and hypotheses}

\subsection{MNEs in context}

What firms do, depends on both the formal and informal regulations specific to the context in which they operate (Brewster et al., 2008). As MNEs straddle national institutional domains, they are only partially rooted in each of the countries in which they operate (Morgan \& Kristensen, 2006). Hence, we argue that MNEs will be more sensitive to internal corporate governance mechanisms than their domestic counterparts will, and hence, they form the primary focus of this study.

\subsection{Board composition: Varieties of director}

In considering the composition of boards, a key distinction is between "outside" directors and "inside" ones (Johnson et al., 1996, p. 417). The latter represent board members who are employees of the firm (Hermalin \& Weisbach, 1988; Peng, 2004). Some scholars claim that inside directors tend to exhibit risk aversion behavior in entry strategy selection (Judge, 2012) because they face losing their jobs in the event of an unsuccessful strategy. This discourages the firm from adopting internationalization strategies at all and may hamper the extent of the firm's internationalization (Filatotchev et al., 2001).

From an agency perspective, inside directors who want to protect their relationship with the firm cannot objectively monitor the family members' activities (Anderson \& Reeb, 2004). To maintain their position in the firm, they will choose to take sides with the founding family members who control the firm. Agency approaches further suggest that the desire of family members to protect their interests results in other investors being left worse off (Morck \& Yeung, 2003; Bugra, 2007). However, the importance of family - and the strategic extension 
of family ties - may increase pressures to invest in or support the business interests of other members of the extended family (Morck \& Yeung, 2003), which may focus the firm on local investments, rather than taking substantial stakes in foreign affiliates. Zahra (2003) argues that a focus on family orientated concerns will mitigate against investments abroad. Family firms may become conservative over time and be unwilling to enter new or unfamiliar environments and prefer to operate within zones family members are familiar with (Zahra, 2005). This may entail foregoing significant business opportunities abroad. If inside directors lack independence from the family, then they will be likely to share their expected aversion to high levels of equity ownership abroad. Hence:

Hypothesis 1a. The ratio of inside directors (that is directors who are employed by the firm, but not family members), will be negatively associated with the extent of equity ownership of EM MNE affiliates.

Independent directors are those who have no material relation with the firm except for board membership, this would include outside directors who have no family relationship (Anderson \& Reeb, 2004; Peng, 2004; Usdiken \& Yildirim-Oktem, 2008). Beneficial investor business opportunities, including internationalization, may be missed because of the abovementioned local bias by family members and their proxies. Hence, agency theory would hold that they serve a vital role in protecting the interests of minority shareholders against families and their managerial placemen (Rhoades \& Rechner, 2001; Peng, 2004; Morck \& Yeung, 2003). When independent directors dominate the board, they may dilute such pressures.

Nonetheless, Bugra (2007, p. 286) found that independent directors lacked the ability to question the founding family members' decisions. Hence, independent directors' role on the board may not go much beyond enhancing the prestige of the company (Selekler-Goksen \& Karatas, 2008). It is unlikely that family members would authorize the independent directors to promote the minority shareholders' interests, which are not congruent with their own (Bugra, 2007). Consequently, it is not the presence of independent directors that matters, but whether they are actually able to genuinely have an impact. If family members are confident 
in their ability to reign in independent directors and ensure that they promote family interests, then they will not so much seek to insist on a fixed number of independent directors, but rather will be guided by whether or not they can impose effective control on them. Indeed, a large number of compliant independent directors subject to influences of members of the owning family may amplify the latter's concerns rather than those of other shareholders. In addition, such family members are likely to prefer that investment is directed towards other businesses in which the family has an interest, rather than new ventures abroad. Hence, in EM contexts, where family ownership is widespread, even among MNEs, we hypothesize that:

Hypothesis 1b. The ratio of independent directors (that is, neither family members nor employed by the firm) will be negatively associated with the extent of equity ownership of EM MNE affiliates.

In the case of family owned businesses, there is a tendency for management to be transferred from generation to generation. In EMs, marriage alliances (as frequently observed in Turkey [Bugra, 2007]) represent a mechanism for extending the influence of business families. Applications of agency theory to family businesses hold that a common agency failing arises from divergences of interests between family members and minority shareholders (Anderson \& Reeb, 2004). Family members may be reluctant to invest abroad both on account of the need to provide investment capital for relatives and/or because of a preference for conducting business within the comfort zone afforded by family-based networks. If family members are well represented on boards, they may use their position to force the firm to concentrate investments on the home market, potentially leaving minority shareholders worse off. Conversely, if families are in a weaker position on boards, then other shareholders may be able to drive greater internationalization when opportunities emerge (Fernandez \& Nieto, 2006).

Hypothesis 1c. The ratio of family directors will be negatively associated with the extent of equity ownership of EM MNE affiliates. 


\subsection{Size of family stake vs. overseas equity ownership}

In family owned businesses, there may be pressures to concentrate investments favorable to other businesses owned by extended family members, making firms more reluctant to channel resources to more remote destinations (Morck \& Yeung, 2003). Zahra (2005) argues that a tendency for family businesses to become inward looking and focused towards family-based networks may mitigate against a willingness to invest in unfamiliar contexts. Cerrato and Piva (2012) found that when family influence is diluted by outside and foreign - shareholders such firms were more likely to take larger stakes abroad. Similarly, Sciascia et al. (2012) note that family dominated firms may be internationally entrepreneurial when levels of family equity ownership is moderate. The reason for this is that the ratio of the family's own funds invested abroad is less and the costs (and uncertainties) are shared with other investors. There may be a further agency issue: family members may be under pressure to invest in businesses held by family members in the diaspora (Stewart, 2003), and this can be rendered more palatable if outsiders bear some of the costs. Hence:

Hypothesis 2. The ratio of equity stake held by family directors will be negatively associated with the extent of equity ownership of EM MNE affiliates.

2.4. The moderating impact of institutional distance on the relationship between board composition, family ownership and foreign equity ownership strategy

Based on Scott's (2001) classification of institutions, institutional distance is defined as the extent of dissimilarities between the institutional settings of home and host countries (Kostova, 1999; Xu \& Shenkar, 2002; Gaur \& Lu, 2007). The institutional differences between the home and host countries significantly affect the MNE's strategic decisions (Ando, 2012). Many studies report that the institutional dissimilarities between home and host countries impact directly, or moderate, various facets of entry mode strategies of MNEs (e.g. Davis et al., 2000; Yiu \& Makino, 2002; Eden \& Miller, 2004; Xu et al., 2004; Gaur \& Lu, 
2007; Meyer et al., 2009; Demirbag et al., 2010a; 2010b). In new and unfamiliar institutional environments, MNEs encounter added costs of doing business abroad and competitive disadvantage (Eden \& Miller, 2004). The institutional distance increases external uncertainty as perceived by MNEs (Gaur \& Lu, 2007); causes difficulty in transferring organizational practices, knowledge and strategic resources abroad (Kostova, 1999); intensifies the liability of foreignness (Ando, 2012); causes difficulty in managing the local environment (Xu \& Shenkar, 2002); and increases transaction and coordination costs of production (Demirbag et al., 2007; Arslan \& Larimo, 2011). Gaur and Lu (2007) classified these costs as unfamiliarity hazards and relational hazards.

There is an extensive body of work evaluating the effects of institutional distance on entry and subsequent strategic choices of MNEs (Campbell et al., 2012; Schwens et al., 2011; Tihanyi et al., 2005). However, recent strands of institutional thinking suggest that the relationship between formal structures and action is neither direct nor deterministic (Wood \& Lane, 2012). Specific patterns of close inter-personal and familial ties may coalesce to constitute an informal regulatory structure, especially when formal institutional arrangements are poorly coupled or fluid (Goodwin et al., 1993). Hence, Johansen and Schoar (2006) found that, even when controlling for institutions, family ties had a direct impact on organizational outcomes. Indeed, embedded family ties may provide the primary framework for decision making, with variations in home and host country formal institutional arrangements failing to even exert a moderating effect (Goodwin et al., 1993). Consequently, in this study, we emphasize the role of formal institutions in moderating embedded family ties and associated informal regulatory mechanisms.

The superior knowledge and links of local partners can assist MNEs to overcome alien environments and institutional distance, thereby increasing recognition. Nevertheless, the problems of working with indigenous partners should not be ignored. In these environments, the selection of an indigenous partner is itself a challenge (Anderson \& Gatignon, 1986; Demirbag et al., 1995). A greater institutional distance between the home and host countries makes interacting with local agents more challenging (Ferreira et al., 2009). It becomes increasingly harder to find reliable local partners the more the institutional distance increases 
(Gaur \& Lu, 2007). Local partners are likely to act opportunistically, therefore, higher levels of coordination and monitoring is needed (Gomes-Casseres, 1990), and the distance increases the costs of overall governance (Demirbag \& Mirza, 2000; Xu \& Shenkar, 2002; Eden \& Miller, 2004; Chao \& Kumar, 2010). In this context, the relational hazard costs may exceed the costs stemming from unfamiliarity hazard.

It has commonly been held that a lower level of equity ownership mitigates risk: The stakes are much lower should something go wrong, with risk being shared between investors (Folta \& Ferrier, 2000). Local partners may also possess superior intelligence as to country of domicile dynamics, and reduce risk (Rugman, 2003). Consequently, firms may work to ensure greater centralization in ownership and control to mitigate risk (Hoskisson \& Hitt 1988; Killing, 1983; Gomes-Casseres, 1990; Demirbag \& Weir, 2005; Beamish \& Lupton, 2009). This enables greater internal coherence and alleviates the risks of falling foul of a powerful local partner (Gaur \& Lu, 2007). Hence, John et al. (2008) argue that when investor rights are weak or uncertain, outright control may be a preferred option. It can be argued that EM investors may be better equipped to understand the uncertainties and challenges of doing business in other similar contexts than their peers from developed economies. When they enter less familiar countries, they may prefer more direct and closer control, as relational costs escalate. Accordingly, it may be argued that institutional distance moderates the effect of the board composition on the equity ownership level.

Faced with substantial dissimilarity in institutions, EM firms will attempt to overcome these costs and external uncertainty by raising the degree of control over foreign affiliates (Ando, 2012). Even if the board size is large, or there are more independent and inside directors, the management board will still reflect the expectations of founding family members and/or majority shareholders. Indeed, if outsider directors are drawn from family members' networks, they may amplify them. Hence:

Hypothesis 3a. Institutional distance positively moderates the relationship between the ratio of inside directors and the extent of equity ownership of EM MNEs in their affiliates. 
Hypothesis 3b. Institutional distance positively moderates the relationship between the ratio of independent directors and the extent of equity ownership of EM MNEs in their affiliates.

It is likely that family members will exhibit risk-averse preferences, given their desire to protect their own and their families' interests. In turn, this would reflect an interest in guarding their socio-economic wealth and status. Gómez-Mejía et al. (2007) found that even if the resultant strategic choices made might reduce returns, families would persist with them if they were seen as effective in mitigating risk. Fattoum-Guedri et al. (2017) suggested that this risk aversion would feed into a desire to ensure a high degree of control, even if, again, this might be bad for returns. This does not mean that all family businesses are closed, inward looking or wedded to a specific locale. Indeed, Kraus et al. (2018) found that many family owned businesses were open minded about seeking out new opportunities, even if this went hand in hand with risk aversion. In looking abroad, such firms may seek to decrease relational hazard costs and ensure close control of affiliates in environments about which they are likely to know little (c.f. Bugra, 2007; Wood et al., 2014b). If there is a large representation of family directors on the board, and/or if the equity stake by family directors is relatively high, then they are more likely to be able impose a risk mitigation agenda. Hence:

Hypothesis 3c. Institutional distance positively moderates the relationship between the ratio of family directors and the extent of equity ownership of EM MNEs in their affiliates.

Hypothesis 3d. Institutional distance positively moderates the relationship between the ratio of equity stake held by family directors and the extent of equity ownership of EM MNEs in their affiliates.

\section{Research methods}

\subsection{Context}

Our study is conducted in an EM context, and we adopt Turkey as the site of the study. There are several reasons for adopting Turkey as the context of this study. Turkey's 
institutional environment has much in common with other EMs (Cavusgil et al., 2002). For instance, in addition to a high degree of family ownership and the traditional family-based model of the firm, Turkey evinces many of the pronounced characteristics of a weak corporate governance regime, with poor law enforcement and protection for owner rights, recent reforms notwithstanding (Yurtoglu, 2003; Demirag \& Serter, 2003; Ararat, 2011). Yurtoglu (2000) classifies Turkey as having an "insider system”. Such countries typically lack external mechanisms for managerial control, which means that internal controls, such as board of directors, become more significant for corporate governance (Mak \& Li, 2001; Guillen \& Capron, 2016).

The primary concern confronting large business groups in many EMs, such as Turkey, is board professionalization (Amsden \& Hikino, 1994; Guillén, 2000; Demirag \& Serter, 2003; Bugra, 2007; Yildirim-Oktem \& Usdiken, 2010). Founding family board members often wish to maintain control over the company (Bugra, 2007) and undertake a more active role in the strategic decision-making of affiliated firms (Selekler-Goksen \& Yildirim-Oktem, 2009). In Turkish firms, on average more than one-third of all board members are large shareholders (Yurtoglu, 2000). Firms have a "one-tier board system" where managing executives are also represented on the board (Yurtoglu, 2000). The link between management boards and the internationalization process has become a strategic concern for EM-based firms following liberalization (Toulan, 2002). Existing evidence from Turkey suggests that board member features have a major influence on the internationalization performance of affiliates (Selekler-Goksen \& Yildirim-Oktem, 2009).

\subsection{Sample}

The unit of analysis in this study is the affiliate. The sample consists of a total 374 foreign affiliates of 71 publicly listed Turkish MNEs on the Istanbul Stock Exchange (BIST). The firms were chosen through a judgmental sampling procedure with respect to the following selection criteria: (1) We excluded parent firms in the banking and finance sectors because generally they do not adopt FDI strategies and have board compositions that differ from other firms. (2) We selected parent firms with at least 10 per cent ownership of affiliates, 
as this range is consistent with the related literature (Tatoglu \& Glaister, 1998; Larimo, 2003) and appropriate for the overall aims of this study; FDIs with less than 10 per cent foreign shareholdings are denoted as portfolio investments (Tatoglu \& Glaister, 1998). (3) We selected parent firms with at least one foreign affiliate at the minority joint venture level. The affiliates in the sample operate in a total of 61 countries, around half of which are EMs and the other half are developed country markets.

\subsection{Measures}

The following subsections include the definitions and measurements of the variables used in the study.

\subsubsection{Dependent variable}

The level of foreign equity stake adopted by Turkish MNEs to enter foreign countries was treated as the dependent variable. This variable was measured by the ratio of equity stake held by the Turkish MNE in its affiliate based in the host country. The foreign equity ownership level was drawn from the Public Disclosure Platform and the firm's yearly reports.

\subsubsection{Predictor variables}

With reference to previous research (e.g. Rhoades \& Rechner, 2001; Filatotchev et al., 2001, 2008; Lien et al., 2005; Kaymak \& Bektas, 2008; Selekler-Goksen \& Karatas, 2008; Lu

et al., 2009; Yildirim-Oktem \& Usdiken, 2010; Filatotchev \& Wright, 2011), board composition was measured as the ratio of independent directors, the ratio of inside directors and the ratio of family members. The equity stake held by family board members was measured by the ratio of the equity stake held by family board members. Details of measurement of these variables are provided in Appendix A.

\subsubsection{Moderator variable}

We used the institutional distance between home and host countries as the moderator variable. Firstly, consistent with prior literature (e.g. Gaur et al., 2007; Arslan \& Larimo, 
2010; Chao \& Kumar, 2010; Hernández \& Nieto, 2015), we evaluated the institutional distance at regulative and normative levels. While there are several reports and databases published by different institutions to measure the dimensions of institutional aspects, they all vary in terms of the publication year, the countries analyzed, scales and constructs used. The data for these institutional dimensions were taken from the Global Competitiveness Report 2015-2016 published annually by World Economic Forum (2015) (see Appendix A for detailed information of their measurement). It is one of the most commonly used databases in the literature where the various editions of this database have been utilized to measure the differential effects of institutional distance (e.g. Xu et al., 2004; Gaur et al., 2007; Kaynak et al., 2007; Chao \& Kumar, 2010). Secondly, the structural validity of the regulative and normative institutional distances was tested by exploratory factor analysis. Principal component analysis with varimax rotation method was conducted for examining the factor structure of these variables. The results of the factor analysis reveal that all sub-dimensions of these institutional distance variables are loaded in one factor. This factor explained 78 per cent of the total variance in the data (Kaiser-Meyer-Olkin measure of sampling adequacy $=$ 0.921; Barlett's test of sphericity $=926.662 ; p<0.01)$. The internal consistency of this factor was high $(\text { Cronbach's alpha }=0.967)^{1}$. In light of these analyses, all sub-dimensions of the two institutional distance variables are loaded in only one dimension. This one dimension, labeled 'institutional distance', was used in this study ${ }^{2}$.

\subsubsection{Control variables}

Three categories of control variables are included. Parent company level controls comprise board size, unrelated product diversification and international diversification. Host country level controls include minority shareholder protection, cultural distance, geographic

\footnotetext{
${ }^{1}$ The details of the results of the structural validity and internal consistency of the variables are not reported here because of page limitations. However, they are available on request.

${ }^{2} \mathrm{We}$ examine the moderating effects of regulative and normative institutional distances between a MNE's home and host countries separately on the relationship between board composition, family ownership and foreign equity ownership level. There are no differences between the results of the one dimension as the institutional distance and two dimensions as regulative and normative institutional distances separately. The results of both institutional distances analyzed separately are available on request.
} 
distance, linguistic distance, corruption distance, country risk and emerging market. Affiliate level controls are affiliate size and industry.

\section{Parent company level controls}

In Turkey, as in many EMs, boards of directors are expected to promote the founding family shareholders' interests over those of minority shareholders. A large board does not mean that outsider and non-executive directors, who are assumed to protect minority shareholders' rights, can effectively represent their interests (Selekler-Goksen \& YıldırımOktem, 2009). Regardless of size, the ratio of outside members, independent members and non-executive members, whose functions are controversial in the Turkish context, may be modest (Usdiken \& Y1ldırım-Oktem, 2008). Given that different parts of an extended family are more likely to be represented in a larger board, and that each will have an interest in protecting their own commercial interests, it may be harder to forge agreement around a major new commitment to an overseas market. Hence, it can be expected that an increase in board size leads a firm to choose a low proportion of equity stake in the foreign affiliate.

International diversification denotes the extent to which Turkish MNEs operate in dissimilar host markets or regions (Hitt et al., 1997). International diversification may increase MNEs' risks because of augmented administrative uncertainties and complexities associated with operating in new host country environments (Tihanyi et al., 2005). Thus, we envisage Turkish MNEs to prefer equity shareholding in their affiliates in order to mitigate the potential risks arising from cultural and institutional dissimilarities between home and host country operations.

Unrelated product diversification can be defined as the degree to which firms extend their businesses by developing new product markets (Hitt et al., 1997). Consistent with previous studies (e.g. Demirbag et al., 2009), we expect that such diversified Turkish MNEs are more likely to choose a lower level of equity shareholding in their affiliates.

\section{Host country level controls}


Property rights centered approaches to corporate governance set great store by minority shareholder protection (La Porta et al., 2000b). It is argued that in the absence of this, a large shareholder(s) may collude with managers to serve their mutual interests, leaving other shareholders much worse off. Kim et al. (2007) conclude that strong minority shareholder protection leads to boards that are more independent. In other words, it is harder to sustain a board rigged in favor of managers and a majority shareholder.

While the findings of prior studies on the effect of cultural distance on MNEs' choice of a particular equity ownership mode in their affiliates show some mixed evidence (Brouthers \& Brouthers, 2001), we adopt the viewpoint that when EM MNEs access foreign markets, that are culturally dissimilar from their home countries, they would be driven by a specific motive to learn how to do business in the host country market, thus encouraging them to opt for a lower equity shareholding in their affiliates (Demirbag et al., 2009).

The notion of geographic distance has been indicated to be a major factor influencing strategic decisions of MNEs related to the control and ownership of their foreign affiliates (Contractor et al., 2016). Turkish MNEs confront a growing level of information asymmetry as geographic distance increases, which makes it highly onerous when making an equity ownership decision. Thus, we assume that Turkish MNEs may prefer a lower equity stake in their affiliates to address the problems emanating from high level of information asymmetry in geographically distant locations (Malhotra \& Gaur, 2014).

With the exception of a few studies (Dow \& Karunaratna, 2006; Demirbag et al., 2007; Malhotra \& Gaur, 2014; Contractor et al., 2016), a linguistic distance measure has not been operationalized in equity ownership strategies of MNEs. Particularly for EM MNEs, a linguistic distance measure may complement that of cultural distance owing to the regional orientations of their operations (Demirbag et al., 2007). A high level of linguistic distance between home and host countries will affect the equity ownership decisions of Turkish MNEs for their affiliates by influencing managers' attitudes towards risk.

Country risk is defined as the uncertainty resulting from the economic, social, political and legal contexts of the host country (Quer et al., 2007). A greater degree of country risk will lead Turkish MNEs to select a lower equity stake in their affiliates. 
In line with prior studies (e.g. Demirbag et al., 2007), we assume that as the level of corruption distance grows, Turkish MNEs are likely to choose a lower equity shareholding in their affiliates.

It is widely acknowledged that institutional voids in host country markets exist in both developed countries and EMs, though the extent or threat of such voids may vary between the two groups. Hence, we control the nature of host country market (emerging vs. developed country) on ownership strategies of Turkish MNEs (Demirbag et al., 2009).

\section{Affiliate level controls}

Empirical evidence is somewhat equivocal with regard to the impact of affiliate size on equity ownership choice of MNEs. While some studies suggest that MNEs are more likely to prefer a lower equity stake in their affiliates when affiliate size is great (Gatignon \& Anderson, 1988), others indicate that MNEs are likely to select full ownership or a higher equity stake in their affiliates as the size of operation increases (Zhao \& Zhu, 1998; Demirbag et al., 2009). Given that the Turkish context still poses a great degree of risk and uncertainty, we assume that Turkish MNEs will select lower equity ownership in their affiliates as the affiliate size increases.

To control for industry variations, the sample of affiliates was assigned into the three categories of manufacturing, service and tertiary industries.

Details of measurement of these variables are provided in Appendix A.

\section{Data analysis and results}

Ordinary least squares regression (OLS) analysis was conducted to test the relationships between board composition, family ownership and foreign equity ownership strategy (Hypotheses 1a, 1b, 1c and 2) and the moderating effect of institutional distance (Hypotheses 3a, 3b, 3c and 3d). Both the independent variables and the moderator variable were centered according to the procedure proposed by Aiken and West (1991). A moderator is "a qualitative or quantitative variable that affects the direction and strength of the relationship between a dependent and an independent variable" (Baron \& Kenny, 1986, p. 1174). To test 
the sensitivity of the results, we also utilized the Tobit regression procedure, as this technique has been widely used in prior research concerning equity ownership decisions of MNEs in their affiliates, when the dependent variable is censored or truncated (Delios \& Beamish, 1999a; Chadee \& Qiu, 2001; Pan, 2002; Meyer et al., 2014)³. Table 1 displays the descriptive statistics and the correlation coefficients between the dependent, independent and moderator variables.

\section{Insert Table 1 here}

The pairwise correlations do not indicate severe collinearity problems for the regression analyses, being in the acceptable range (well below 0.80) (Gujarati, 1995; Kennedy, 1999). The variance inflation factors (VIFs) of all variables are far below the acceptable threshold point (equal to or below 10) (Freund et al., 2006). Thus, multicollinearity in models is not a serious concern in this study. There exist, however, high correlations between several control variables and institutional distances, which may produce multicollinearity problems. Consequently, we do not include the control variables of corruption distance, country risk and emerging market in the models containing the moderating variable.

\subsection{Main effects of board composition and family ownership}

Using both OLS and Tobit regression procedures, Table 2 shows the models containing the direct effects of board composition (Model 1 through Model 5) and the interaction effects of institutional distance and board composition (Model 6 through Model 9) on the foreign equity ownership strategy of Turkish MNEs. The results are strongly consistent across OLS and Tobit specifications. Model 4 shows the full model including all independent and control variables. Apart from the ratio of family members and the ratio of the equity stake held by family board members, the other board composition variables have significant coefficients on the equity ownership choice of their affiliates.

\footnotetext{
${ }^{3}$ Although Tobit analysis is more suitable when the dependent variable is censored or truncated, in our sample there are only three FDIs with less than 10 per cent foreign shareholdings. Hence, OLS regression is far from yielding coefficient estimators that are biased. The results of the two estimating methodologies are found to be in close conformity in terms of the pattern of parameter significance.
} 
H1a posits that the ratio of inside directors is negatively linked to the level of foreign equity ownership of MNEs. The coefficient on the ratio of inside directors is marginally significant and positive in Models 2 to $5(p<0.05)$, but not significant in Model 1 , hence, no support is found for H1a. This implies that the higher the number of manager-directors, the more likely that there will be a higher level of equity ownership of affiliates. This could reflect the extent to which managers may seek to dilute family influence, through exposing the firm to different and potentially stronger institutional pressures. As the literature on institutions and the firm alerts us, the stronger and more developed formal institutions are, the harder it is to sustain the traditional model of the family dominated firm (Church, 1993).

The ratio of independent directors displays negative and significant coefficients in Model $1(p<0.01)$ and Model $2(p<0.05)$. These findings confirm H1b suggesting that the higher the ratio of independent directors the lower the level of equity stake held by MNEs. In other words, nominally independent directors have the effect of amplifying, rather than diluting the effects of family ownership.

According to Model 1 through Model 5, there is no support for either H1c or H2. The coefficients of the ratio of family members and the ratio of the equity stake held by family board members are not significant in all four models. This could reflect the ability of families to impose their influence by other means, for example, through the operation of informal family-based networks.

Table 2 shows that the coefficient of institutional distance is insignificant in Model 5 showing the main effects. This implies that the differences in institutional environment between the home and host countries do not have any direct effect on the ratio of equity stake held by MNEs.

As shown in Table 2, when the control variables are included (Models 2 to 5), two of the parent level controls, board size and unrelated product diversification have negative and significant coefficients. This confirms that MNEs that have a larger board size $(p<0.05)$ and characterized by high level of unrelated product diversification $(p<0.01)$ prefer a lower equity mode. Only one of the three affiliate level controls, affiliate size has a negative and 
significant coefficient $(p<0.05)$ in Models 3 to 5 . None of the host country related variables are statistically significant.

\subsection{Moderating impact of institutional distance}

The results of the moderating effect of institutional distance on the linkage between the corporate governance mechanism of board composition and equity ownership strategies of MNEs are shown in Model 6 to Model 9 of Table 2. If the interaction term is significant, this signifies that the effect of the board composition on the level of equity shareholding held by MNEs in their affiliates is identified somewhat by the institutional distance between home and host countries (Zeitner, 1998). In such circumstances, institutional distance significantly moderates the relationship between the board composition and equity-based ownership strategy.

In Table 2, there are four models (Models 6 through Model 9) that examine interactions between the institutional distance and board composition. Both $F$ statistics and $L R \chi^{2}$ in all four regression equations are significant $(p<0.01)$ and hence are useful for explanation purposes. It should be noted that there is not substantial augmentation of adjusted $R^{2}$ values in the models where the moderators are added. This is not surprising in empirical studies of this nature, when there are several common variables (board composition and control variables) used together (Agresti \& Franklin, 2013; McClean et al., 2013). As shown in Models 6 to 9 of Table 2, the interaction effects between institutional distance and the board composition variables of the ratios of independent directors, family members and the equity stake held by family board members are positive and statistically significant $(p<0.05, p<0.05, p<0.01$, respectively) providing support for $\mathrm{H} 3 \mathrm{~b}, \mathrm{H} 3 \mathrm{c}$ and $\mathrm{H} 3 \mathrm{~d}$, respectively. The negative interaction effect between institutional distance and the ratio of inside directors is also statistically significant $(p<0.05)$ but contrary to our expectation in $\mathrm{H} 3 \mathrm{a}$, which is accordingly rejected. These results show that institutional distance positively moderates overall the relationship between board composition (except the ratio of inside directors) and MNEs' equity ownership 
in their affiliates. However, the interactions between all the board composition variables and institutional distance reverse the signs of their main effects. We sought to clarify these effects further by comparing high and low institutional distance levels by plotting graphs (Figures 2A to 2D). These effects are interpreted in line with Aiken and West (1991).

The simple slope analysis (Aiken \& West, 1991; Cohen et al., 2003), as shown in Figure $2 \mathrm{~A}$, indicates the effect of interaction between the ratio of inside directors and institutional distance on the extent of MNEs' equity stake in their affiliates. The ratio of inside directors has a positive effect on equity ownership at a low level of institutional distance $(\beta=34.232, p$ $<0.01$ ), while it has no significant effect on equity ownership at a high level of institutional distance, which is contrary to our expectation in H3a. This means that when institutional distance is low, the greater the ratio of inside directors, the higher the level of the equity stake held by MNEs in their affiliates.

Figure $2 \mathrm{~B}$ shows the interaction effect between the ratio of independent directors and institutional distance. As shown in Figure 2B, the ratio of independent directors has a negative effect on the equity ownership level of MNEs in their affiliates when institutional distance is at a low level $(\beta=-47.572 ; p<0.01)$ while it has no significant impact on equity ownership when institutional distance is at a high level. That is, when institutional distance is low, the greater the level of the ratio of independent directors the lower the level of equity stake held by MNEs in their affiliates. This finding supports $\mathrm{H} 3 \mathrm{~b}$, suggesting that when institutional distance is low, the relationship between the ratio of independent directors and the level of equity shareholding of MNEs in their affiliates is negative.

Insert Figures 2A and 2B here

Figure $2 \mathrm{C}$ shows the interaction between the ratio of family directors and institutional distance. This plot indicates a positive relationship between the ratio of family directors and equity ownership level when institutional distance is high $(\beta=7.576, p<0.05)$ and a negative relationship when institutional distance is low $(\beta=-20.542, p<0.05)$. This means that where institutional distance is high, the greater the ratio of family directors on the board the greater the MNE's equity ownership in its affiliates. When institutional distance is low, the greater 
the ratio of family directors then the lower the foreign equity ownership level. This finding confirms our expectations for $\mathrm{H} 3 \mathrm{c}$, in that the link between the ratio of family directors and the extent of equity stake held by MNEs in their affiliates is positive when institutional distance is high.

In a similar vein, Figure 2D displays the plot of the interaction between the ratio of the equity stake held by family board directors and institutional distance on MNEs' equity ownership level in their affiliates. Simple slope analyses reveal that the proportion of the equity stake held by family board directors has a positive effect on the equity ownership when institutional distance is high $(\beta=0.703, p<0.01)$, while there is not a significant effect on the ownership equity level when institutional distance is low. At a high level of institutional distance, the higher the proportion of the equity stake held by family board directors, the more likely that MNEs choose a high level of equity ownership in their affiliates. This finding supports $\mathrm{H} 3 \mathrm{~d}$, that when institutional distance is large, the link between the ratio of the equity stake held by family board directors and the level of MNEs' equity stake in their affiliates is positive.

\section{Insert Figures 2C and 2D here}

\section{Discussion and conclusions}

This study examines how the corporate governance mechanism of board composition and institutional distance impacts the foreign equity ownership strategies of MNEs, according particular attention to the consequences of family ownership. Recent work by Ilhan-Nas et al. (2018), focused exclusively on the effects of ownership concentration and institutional distance on the equity-based ownership strategies of Turkish MNEs. This study adds to the literature by examining both the direct effects of board composition and the interaction effects of board composition and institutional distance on foreign equity ownership strategies. Specifically, there is a much more finely grained focus on institutional effects, deploying recent advances in the literature on comparative capitalism. Furthermore, the study sheds light on the interplay between internal and external corporate governance. The findings highlight the limits of agency theory as a universally applicable explanatory tool, especially in the 
context of EMs. From a broad historical and institutional perspective, there is a body of literature, which, whilst acknowledging that a number of Western family businesses retain the traditional characteristics of such firms, there are many that no longer do so (Jones \& Rose, 1993). For example, Church (1993) argues that in the developed world, family ownership matters much less than institutional setting and internal corporate culture. Boltanski and Chiapallo (2000) argue that the disorganized and arbitrary nature of the traditional family enterprise has been supplanted through modern managerial methods and systems. In contrast, in the developing world, it has been argued that the family firm retains its traditional characteristics, which prioritize patriarchal control, and a focus on family decision-making rather than objective systems. Indeed, as part and parcel of neo-liberal reforms, privatizations have enabled influential families to acquire significant new assets. In Turkey, this is similarly the case (Gökarıksel \& Secor, 2009), albeit that there has been a consolidation of wealth in the hands of a few such families with strong ties to the political elite and the military. Recent political developments have resulted in a certain dynamism to the system, with some families that were in official favor in the past now being less so, and vice versa. In practical terms, this implies that formal corporate governance mechanisms matter less than the informal solutions derived by families to solve particular corporate problems. This study confirms that whilst specific internal corporate governance structures matter, of equal or greater importance is the role of dominant families and the patterns of strategies they adopt to secure their interests.

A primary finding is that increasing the ratio of independent directors on the board leads to a reduced willingness to take larger stakes in overseas affiliates. This is not consistent with the predictions of agency theory, but it is consistent with our expectations. In Turkey, family dynamics and self-control problems combine and undermine the effectiveness of independent directors (Schulze et al., 2001) because they almost never acquire the status of large-block ownership. Independent directors accordingly behave like family members in favoring investments at home, given that they are appointed to directorship positions by owning families. Independent directors are included on the board in order to comply with external institutional pressures rather than to secure better internal corporate governance (Usdiken \& Yildirim-Oktem, 2008). As Zattoni and Cuomo (2010) note, the incentives provided to, and 
competencies of, independent directors have often been neglected as a governance issue. Yet, particularly in EMs, where the pool of suitably qualified individuals may be small, and the role of personal networks more extensive, relative independence may vary. Being an independent director may be accorded more prestige in society and the financial incentives provided may be proportionately much more attractive. This suggests that individuals will be more likely to become non-executive directors for the wrong reasons, less out of a sense of calling, and more because of the rents that accrue from the position. Hence, even if internal corporate governance matters much more in contexts where external corporate governance supports are weak, they may be much more difficult to secure (Klapper \& Love, 2004). Consequently, independent directors may amplify, rather than dilute the effects of family ownership.

When we include the moderating impact of institutional distance, as expected, the greater the number of (nominally) independent (but quite probably family aligned) directors the more MNEs select a lesser equity ownership level in their affiliates at low institutional distance between home and host countries. This reflects the extent to which the desire to concentrate investment towards family-based businesses at home may be outweighed by the desire to closely scrutinize investments in unfamiliar environments. Such investments may be prompted by other factors, for example, wealthy families from politically uncertain environments may seek to invest significant amounts of their own funds in perceived safe havens in the developed world, and those with low tax regimes. In such instances, the immediate business case for such investment may be outweighed by the desire to hedge risk in the long term. Many countries, from the UK to Malta, grant preferential immigration status to those individuals (and their immediate families) who invest large amounts in them. If some investments perform better than others, access to a safe haven may be seen as priceless.

With respect to inside directors, a greater presence of insiders on the board is similarly positively linked to the extent of equity stake held by MNEs in their affiliates. In contexts where family ownership is relatively high, insiders may choose to take sides with the founding family members, in order to be able to maintain their position in the firm. Therefore, insiders prefer less risky entry strategies. However, and contrary to other evidence from EMs 
(Kaymak \& Bektas, 2008; Lu et al., 2009), the findings suggest that the presence of professional managers encourages the taking of majority stakes. This may be to dilute family power. The traditional model of the family firm is most easily sustained in the absence of fully developed institutions with advanced complementarities, and hence, it may make it easier for professional managers to secure their agendas and/or take the interests of other investors into account (Church, 1993; Wood \& Lane, 2012).

This positive effect of insiders is observed when the moderated effect of institutional distance is added to the model. EM MNEs, in particular, confront environmental conditions, which are unfamiliar when operating in foreign markets (Yamak \& Usdiken, 2006). Consequently, salaried managers may be better equipped to understand and implement sophisticated methods and structures as they have established skills and technical abilities. Furthermore, owner-families may lack the technical expertise and management abilities of their salaried managers, which might assist in the implementation of more sophisticated organizational and management systems. In this instance, insiders and managers may act as good stewards in managing company assets, and so stewardship theory (Donaldson, 1990) rather than agency theory is supported.

This study is conducted on data from an EM, so we cannot reach conclusions as to the wider applicability of agency theory. However, in the Turkish context, family owners will seek to enforce their rights through internal corporate governance mechanisms and informal ties, rather than reliance on the law. Does this leave minority shareholders worse off? Whatever its imperfections, the traditional family firm model represents an effective and longstanding solution for coping with limitations in regulation and in capital market development (Fainschmidt et al., 2016). The dominance of this model in Turkey suggests that it provides an effective way of coping with challenging circumstances. From a minority investor perspective, whilst investing in a family owned business might be problematic, it provides the opportunity to share the gains presented through the leveraging of extended family networks and patronage when formal institutional arrangements are uneven in their coverage and effectiveness. In other words, it may represent a relatively efficient device for maximizing returns in EM institutional settings, whatever the hypothetical agency problems that might 
emerge. Hence, whilst agency theory may afford insights into the challenges in protecting minority investors in family-controlled firms, it has neglected the extent to which the family firm represents one of the most effective devices for securing returns when formal institutions are weak (c.f. Fainschmidt et al., 2016). Uneven or poor institutional arrangements lead to a lack of protection of minority investors in any case (La Porta et al., 2000a). However, the creative responses of the latter in building ties with systemically influential players may result in better outcomes for them than might at first seem. Although complementarity - that is, the generation of better outcomes than a scrutiny of formal institutions might suggest - is often seen as simply the sum of systemic strengths, in reality it often represents the outcome of attempts to overcome systemic weaknesses (Lane \& Wood, 2012). In summary, the application of agency theory to EMs may be unduly pessimistic as to the relative efficiency of the family firm, and the possibilities for minority investors to optimize their returns.

This does not mean that the interests of families, minority investors, or professional managers, are perfectly aligned. Indeed, as the findings indicate, professional managers may have a shared interest with minority investors in the introduction of modern managerial systems and a more open attitude towards extending geographical scope. In turn, this could weaken the hold of extensive, but informal and geographically confined, family-based mechanisms of control. However, such measures may be to the long-term benefit of family members, even if unpalatable in the short term.

A further noteworthy finding is that there are no main effects with regard to the ratio of family directors and equity stake held by board members on entry strategies of MNEs. The reason for this insignificant effect may be that the average family member $(n=1.85)$ and equity stake held by board members $(10.53 \%)$ is relatively low because of the pyramid ownership structure prevalent in Turkey (Yurtoglu, 2003; Demirag \& Serter, 2003; Bugra, 2007).

Although in many areas of social and economic life, institutions serve an important role in shaping the choices made by firms, in this study, we found that even in a moderating role, institutional distance did not impose much variation in the approaches adopted by family board members (Johansen \& Schoar, 2006; Goodwin et al., 1993), who, regardless of 
circumstances, remained more risk averse than non-family members. We found that the determinants of equity ownership levels in overseas affiliates was primarily a function of board composition and family ownership albeit that institutional effects either moderated or intensified this relationship, rather than exerting direct effects. Prior research would suggest that the ratio of equity stake held by board members has a significant impact on the equity ownership level in affiliates (Demsetz \& Villagonga, 2001; Booth et al., 2002), however, no strong support for this was found in this study. When the moderating impact of the institutional distance is considered, the ratio of equity stake held by board members is positively related to the level of equity stake held by MNEs in their affiliates at high institutional distance. This may reflect a desire to exert closer control in unfamiliar settings. A smaller equity stake held by board members at low institutional distance may reflect greater confidence that their interests will be protected. At low institutional distance, the board composition variable of the equity stake held by board members behaves like family board members. However, the interesting finding is that the ratio of equity stake held by board members is positively linked to the MNEs' equity ownership level in their affiliates, being more in favor of a majority ownership if the host country is a developed country. This could reflect the desire for closer control - and monitoring - of investments in unfamiliar environments. It could also reflect the extent to which families and other holders of equity may use their overseas investments to buy themselves a safe haven abroad, placing their assets in an institutionally more stable environment, and potentially securing for themselves and their relatives a preferential migration status. In contrast, managers without a significant equity stake would not be able to do this. This would reflect less agency or stewardship issues, but rather illustrate how diversity in institutional regimes may be exploited, not just to optimize the utilization of capital, but also as a way of coping with uncertainty.

The findings clearly illustrate that the key antecedent of MNEs' equity shareholding in their affiliates is not the direct effect of institutional distance. Rather, institutional distance has a moderating impact on the link between the corporate governance mechanism and equity ownership strategies. In confirming that institutional distance does not exert a direct effect on relative equity ownership, this study provides evidence that in contexts of institutional fluidity 
and uncertainty, informal relationships and ways of doing things may trump formal regulatory effects. If what sets the traditional family firm apart is that patrimonial power is mediated by informal understandings, then internal corporate governance mechanisms and informal conventions may matter much more than external ones. In contexts where formal rules matter more - that is, in the most developed economies - then Turkish MNEs seem much more reluctant to commit significant amounts of their capital into a single enterprise. In developed economy settings, family investors are better able to enforce their ownership rights through conventional external legal mechanisms, as opposed to internal solutions.

The results relating to the control variables indicate that board size, unrelated product diversification and affiliate size are important antecedents of equity-based ownership strategies of MNEs. In other words, MNEs prefer the less risky equity ownership modes as the board size, the level of unrelated product diversification and affiliate size increase.

\subsection{Implications}

The study highlights the complex and mixed agendas different types of owners and managers may impose on the firm. Rather than seeing either grouping as internally coherent and sharing the same agenda, each is internally diverse. In contexts where the traditional family firm model dominates, family owners rather than relying on the external corporate governance regime, will resort to formal and informal internal governance mechanisms for imposing their agendas, in line with embedded norms of practice. What concerns predominate will, in turn, be closely bound up with the wider context, and the nature and efficacy of overall institutional configurations. This suggests that there is no optimal internal governance structure for EM MNEs, but those seeking to reform internal corporate governance need to take due heed of what has proven to be broadly functional and viable within a specific context, and to consider fully the implications for overseas affiliates, for example, the dilution of family influence may lead to a greater appetite for risk with uncertain consequences.

The existing literature on family capitalism holds that this is a relatively efficient device for managing the challenges posed by incomplete and fluid institutions. Extended familybased networks may impart a greater predictability to exchange relations than a scrutiny of 
formal regulatory efficiency might suggest (c.f. Fainschmidt et al., 2016). They may also provide a basis for coopting local and national power holders. Whilst family-controlled firms may be associated with specific agency problems, minority investors may nonetheless persist with them owing to the advantages that they provide. Existing syntheses between institutional theory and agency theory have tended to focus on formal dimensions of the former (Gaur et al., 2014; La Porta et al., 2000a). However, as the literature on comparative institutional analysis alerts us (Lane \& Wood, 2012), institutions encompass not only formal regulations, but embedded informal rules and understandings, such as that might underpin shared conventions of fair play in the operation of family networks, and informal understandings and accommodations between different categories of investor and other players. This study confirms the importance of the latter and provides insights into the bounded range of outward investment strategies of firms under family capitalism.

For policy makers, the findings suggest that reforms targeting corporate governance practices in general and the formation of management boards in particular, should take into account the role of board composition. For instance, focusing on reforming the functioning of boards by applying simple guidelines, such as limits on the composition of board membership (e.g. ratio of females, insiders and outsiders) and restrictions on the size of the board may be counterproductive or ineffectual, depending on the relative power of existing stakeholders and the strength of their ties with others. For example, there may be a need to recognize and accommodate the dominance of family ownership, and seek to promote mechanisms by which the interests of such families may be reconciled with the needs of other owners and stakeholders, in seeking to develop optimal strategies for investing abroad.

\subsection{Limitations and future research}

Notwithstanding the study's contributions, as is usual, this study has limitations that should be acknowledged when interpreting the results, but also provides avenues for further research. First, the study is confined to a sample of Turkish MNEs. Comparative work contrasting MNEs from emerging and developed markets may shed additional light on the different ways in which family ownership, board composition and institutions interact, and, 
further, on when (i.e. which stage of institutional development) the traditional family firm model (as adverse to family ownership per se) becomes less sustainable. Another limitation is that the study only considers board composition and family ownership, so the nature of our data prevents us from investigating the performance implications of such choice. Moreover, due to data limitations, we were not able to control for the strategic motivations for equity ownership choice. Further, the relative representation of extended family interests versus willingness to venture abroad at all, and the impact of diasporas on the size of ownership stakes in overseas affiliates represents a fruitful area for future research. Finally, there is room for the development and extension of institutional theory to explore in more depth the effects of widespread family ownership, and to locate the choices of key actors within broader structural continuity and change, and vice versa. There are two dimensions to this. A shortfall of the literature on comparative institutional analysis is a tendency to focus on the relationship between formal institutions and macro-economic outcomes, with the firm as something of a transmission belt between the two (Wood et al., 2014a). This study provides insights into the relationship between wider contextual realities, internal corporate governance arrangements and outward investment decisions. The findings suggest that a closer focus on patterns and modes of internal corporate governance might enrich the basis under which different types of capitalism might be compared. This is especially the case given the growing interest in the family capitalism archetype (Fainschmidt et al., 2016). The second is that whilst there have been increasing syntheses between institutional and agency approaches, there has been a tendency to view EM institutions in terms of their negative consequences (c.f. La Porta et al., 2000a). However, whatever their shortfalls, creative actors may still optimize their outcomes than a scrutiny of formal institutional arrangements might suggest: Actors may reach informal compromises to mitigate the negative effects of weak minority investor protections. A closer evaluation of the latter would represent a fertile avenue for future research.

\section{Acknowledgement}

We are indebted to the invaluable comments and feedback of Deputy Editor Dr. Ajai Gaur and three anonymous reviewers. 


\section{References}

Agresti, A., \& Franklin, C. (2013). Statistics: The Art and Science of Learning from Data. 3rd. edition, Pearson.

Aiken, L. S., \& West, S. G. (1991). Multiple Regression: Testing and Interpreting Interactions. Newbury Park, London, New Delhi: Sage Publication.

Almond, P., Edwards, T., Colling, T., Ferner, A., Gunnigle, P., Muller-Carmen, M., Quintanilla, J., \& Wächter, H. (2005). Unraveling home and host country effects: An investigation of the $\mathrm{HR}$ policies of an American multinational in four European countries. Industrial Relations: A Journal of Economy and Society, 44(2), 276-306.

Amsden, A. H., \& Hikino, T. (1994). Project execution capability, organizational know-how, and conglomerate corporate growth in late industrialization. Industrial and Corporate Change, 3, 111-148.

Anderson, E., \& Gatignon, H. (1986). Modes of foreign entry: A transaction cost analysis and propositions. Journal of International Business Studies, 17, 1-26.

Anderson, R. C., \& Reeb, D. M. (2004). Board composition: Balancing family influence in S\&P 500 firms. Administrative Science Quarterly, 49, 209-237.

Ando, N. (2012). The ownership structure of foreign subsidiaries and the effect of institutional distance: A case study of Japanese firms. Asia Pacific Business Review, 18(2), 259-274.

Ararat, M. (2011). Comply or explain without consequences: The case of Turkey. In Mallin, C.A. (ed.), Handbook on International Corporate Governance: Country Analyses. Cheltenham: Edward Elgar Publishing, pp. 355-370.

Arslan, A., \& Larimo, J. (2010). Ownership strategy of multinational enterprises and the impacts of regulative and normative institutional distance: Evidence from Finnish foreign direct investments in Central and Eastern Europe. Journal of East-West Business, 16(3), 179-200. 
Arslan, A., \& Larimo, J. (2011). Greenfield investments or acquisitions: Impacts of institutional distance on establishment mode choice of multinational enterprises in emerging economies. Journal of Global Marketing, 24(4), 345-356.

Baron, R. M., \& Kenny, D. A. (1986). The moderator-mediator variable distinction in social psychological research: Conceptual, strategic, and statistical considerations. Journal of Personality and Social Psychology, 51(6), 1173-1182.

Beamish, P. W., \& Lupton, N. C. (2009). Managing joint ventures. Academy of Management Perspectives, 23(2),75-94.

Berry, H., Guillén, M. F. \& Zhou, N. (2010). An institutional approach to cross-national distance. Journal of International Business Studies, 41, 460-480.

Boltanski, L., \& Chiapello, E. (2000). Le Nouvel Esprit du Capitalisme. Paris: Gallimard.

Booth, J. R., Cornett, M. M. and Tehranian, H. (2002). Boards of directors, ownership, and regulation. Journal of Banking and Finance, 26, 1973-1996.

Bouquet, C., Morrison, A., \& Birkinshaw, J. (2009). International attention and multinational enterprise performance. Journal of International Business Studies, 40, 108-131.

Brewster, C., Wood, G., \& Brookes, M. (2008). Similarity, isomorphism or duality? Recent survey evidence on the human resource management policies of multinational corporations. British Journal of Management, 19(4), 320-342.

Brouthers, K. D., \& Brouthers, L. E. (2001). Explaining the national cultural paradox. Journal of International Business Studies, 32(1), 177-189.

Bugra, A. (2007). Devlet ve İşadamlart (State and Business in Modern Turkey: A Comparative Study), Istanbul: Iletisim Yayincilik.

Campbell, J. T., Eden, L., \& Miller, S. R. (2012). Multinationals and corporate social responsibility in host countries: Does distance matter? Journal of International Business Studies, 43, 84-106.

Carpenter, M. A., \& Fredrickson, J. W. (2001). Top management teams, global strategic posture, and the moderating role of uncertainty. Academy of Management Journal, 44(3), 533-545. 
Cavusgil, S. T., Ghauri, P. N., \& Agarwall, M. R. (2002). Doing Business in Emerging Markets. Thousand Oaks, CA: Sage Publication.

Cerrato, D., \& Piva, M. (2012). The internationalization of small and medium-sized enterprises: the effect of family management, human capital and foreign ownership. Journal of Management \& Governance, 16(4), 617-644.

Chadee, D. D., \& Qiu, F. (2001). Foreign ownership of equity joint ventures in China: A pooled cross-section - time series analysis. Journal of Business Research, 52(2), 123-133.

Chao, M. C., \& Kumar, V. (2010). The impact of institutional distance on the international diversity-performance relationship. Journal of World Business, 45(1), 93-103.

Chen, J., Sokal, R. R., \& Ruhlen, M. (1995). Worldwide analysis of genetic and linguistic relationships of human populations. Human Biology, 67(4), 595-612.

Church, R. (1993). The family firm in industrial capitalism: International perspectives on hypotheses and history. Business History, 35(4), 17-43.

Claessens, S. Djankov, S., \& Lang, L. H. P. (1999). Who controls East Asian corporations, Policy Research Working Paper no. 2054, The World Bank, Washington, November 30. Cohen, J. Cohen, P. West, S. G., \& Aiken, L. S. (2003). Applied Multiple Regression/ Correlation Analysis for the Behavioral Sciences. 3th Edition, Mahwah, New Jersey: Lawrence Erlbaum Associates, Inc.

Contractor, F., Yang, Y., \& Gaur, A.S. (2016). Firm-specific intangible assets and subsidiary profitability: The moderating role of distance, ownership strategy and subsidiary. Journal of World Business, 51(6), 950-964.

Dacin, M. T., Oliver, C., \& Roy, J. (2007). The legitimacy of strategic alliances: An institutional perspective. Strategic Management Journal, 28, 169-187.

Daily, C. M. (1995). The relationship between board composition and leadership structure and bankruptcy reorganization outcomes. Journal of Management, 21, 1041-1056.

Datta, D. K., Musteen, M., \& Herrmann, P. (2009). Board characteristics, managerial incentives, and the choice between foreign acquisitions and international joint ventures. Journal of Management, 35(4), 928-953. 
David, P., O’Brien, J. P., Yoshikawa, T., \& Delios, A. (2010). Do shareholders or stakeholders appropriate the rents from corporate diversification? The influence of ownership structure. Academy of Management Journal, 53(3), 636-654.

Davis, P. S., Desai, A. B., \& Francis, J. D. (2000). Mode of international entry: An isomorphism perspective. Journal of International Business Studies, 31(2), 239-258.

Deephouse, D. L. (1996). Does isomorphism legitimate? Academy of Management Journal, 39(4), 1024-1039.

Delios, A., \& Beamish, P. W. (1999a). Ownership strategy of Japanese firms: Transactional, institutional, and experience influences. Strategic Management Journal, 20(10), 915-933.

Delios, A., \& Beamish, P. W. (1999b). Geographic scope, product diversification, and the corporate performance of Japanese firms. Strategic Management Journal, 20(8), 711-727.

Dellestrand, H., \& Kappen, P. (2012). The effects of spatial and contextual factors on headquarters resource allocation to MNE subsidiaries. Journal of International Business Studies, 43(3), 219-243.

Demirag, I., \& Serter, M. (2003). Ownership patterns and control in Turkish listed companies. Corporate Governance: An International Review, 11(1), 40-51.

Demirbag, M., \& Yaprak, A. (2015). Conclusions and future research directions: Lessons learned from the rise of emerging market multinationals, in Demirbag, M. and Yaprak, A. (Eds.) Handbook of Emerging Market Multinational Corporations, 260-270, Cheltenham: Edward Elgar.

Demirbag, M., Mirza, H., \& Weir, D. (1995). Dynamics of manufacturing joint ventures in Turkey and the role of industrial groups. Management International Review, 35(Special Issue 1), 35-51.

Demirbag, M. \& Mirza, H. (2000). Factors affecting international joint venture success: an empirical analysis of foreign-local partner relationships and performance in joint ventures in Turkey. International Business Review, 9(1), 1-35.

Demirbag, M., \& Weir, D. (2005). Resources and equity ownership in IJVs in Turkey. Thunderbird International Business Review, 48(1), 55-76. 
Demirbag, M., Glaister, K. W., \& Tatoglu, E. (2007). Institutional and transaction cost influences on MNEs' ownership strategies of their affiliates: Evidence from an emerging market. Journal of World Business, 42(4), 418-434.

Demirbag, M., Tatoglu, E., \& Glaister, K. W. (2008). Factors affecting perceptions of the choice between acquisition and greenfield entry: The case of Western FDI in an emerging market. Management International Review, 48(1), 5-38.

Demirbag, M., Tatoglu, E., \& Glaister, K. W. (2009). Equity-based entry modes of emerging country multinationals: Lessons from Turkey. Journal of World Business, 44(4), 445-462.

Demirbag, M., Tatoglu, E. \& Glaister, K. W. (2010a). Institutional and transaction cost influences on partnership structure of foreign affiliates. Management International Review, 50(6), 709-745.

Demirbag, M., McGuinness, M. \& Altay, H. (2010b). Perception of institutional environment and entry mode. Management International Review, 50(2), 207-240.

Demsetz, H., \& Villalonga, B. (2001). Ownership structure and corporate performance. Journal of Corporate Finance, 7, 209-233.

Dore, R. (2008). Best practice winning out. Socio-Economic Review, 6(4), 779-784.

Dow, D., \& Karunaratna, A. (2006). Developing a multidimensional instrument to measure psychic distance stimuli. Journal of International Business Studies, 37(5), 578-602.

Eden, L., \& Miller, S. R. (2004). Distance matters: Liability of foreignness, institutional distance and ownership strategy, Michael A. Hitt and Joseph L. Cheng (ed.), Theories of The Multinational Enterprise: Diversity, Complexity and Relevance, (Advances in International Management, Vol.16), 187-221, Amsterdam, Netherlands: Elsevier.

Elloumi, F., \& Gueyie, J. P. (2001). Financial distress and corporate governance: An empirical analysis. Corporate Governance: International Journal of Business in Society, $1,15-23$.

Fainshmidt, S., Judge, W. Q., Aguilera, R. V., \& Smith, A. (2016). Varieties of institutional systems: A contextual taxonomy of understudied countries. Journal of World Business, 53(3), 307-322. 
Fattoum-Guedri, A., Guedri, Z., \& Delmar, F. (2018). Multiple blockholder structures and family firm performance. Entrepreneurship Theory and Practice, 42(2), 231-251.

Fernández, Z., \& Nieto, M. J. (2006). Impact of ownership on the international involvement of SMEs. Journal of International Business Studies, 37(3), 340-351.

Ferreira, M. P., Li, D., \& Suk, J. Y. (2009). Foreign entry strategies: Strategic adaptation to various facets of the institutional environments. Development and Society, 38(1), 27-55.

Filatotchev, I., \& Wright, M. (2011). Agency perspectives on corporate governance of multinational enterprises. Journal of Management Studies, 48(2), 471-486.

Filatotchev, I., Demina, N., Wright, M., \& Buck, T. (2001). Strategic choices, export orientation and corporate governance in privatized firms in Russia, Ukraine and Belarus: Theory and empirical evidence. Journal of International Business Studies, 32(4), 853871.

Filatotchev, I., Stephan, J., \& Jindra, B. (2008). Ownership structure, strategic controls and export intensity of foreign-invested firms in transition economies. Journal of International Business Studies, 39(7), 1133-1148.

Filatotchev, I., Strange, R., Piesse, J., \& Lien, Y. (2007). FDI firms from newly industrialized economies in emerging markets: Corporate governance, entry mode and location. Journal of International Business Studies, 38, 556-572.

Folta, T. B., \& Ferrier, W. J. (2000). The effect of national culture on partner buyouts in cross-border biotechnology alliances. The Journal of High Technology Management Research, 11(2), 175-198.

Fratianni, M., \& Oh, C. H. (2009). Expanding RTAs, trade flows, and the multinational enterprise. Journal of International Business Studies, 40(7), 1206-1227.

Freund, R. J., Wilson, W. J., \& Sa, P. (2006). Regression Analysis: Statistical Modeling of a Response Variable. Second Edition, USA and UK: Elsevier Inc.

Gatignon, H., \& Anderson, E. (1988). The multinational corporation's degree of control over foreign subsidiaries: An empirical test of a transaction cost explanation. Journal of Law, Economics, and Organization, 4(2), 305-336. 
Gaur, A. S. \& Lu, J. W. (2007). Ownership strategies and survival of foreign subsidiaries: Impacts of institutional distance and experience. Journal of Management, 33(1), 84-110.

Gaur, A. S., \& Delios, A. (2015). International diversification of emerging market firms: The role of ownership structure and group affiliation. Management International Review, 55, $235-253$.

Gaur, A. S., Delios, A., \& Singh, K. (2007). Institutional environments, staffing strategies, and subsisidiary performance. Journal of Management, 33(4), 611-636.

Gaur A. S., Kumar, V., \& Singh, D. A. 2014. Institutions, resources, and internationalization process of emerging economy firms. Journal of World Business, 49(1), 12-20.

Gomes-Casseres, B. (1990). Firm ownership preferences and host government restrictions: An integrative approach. Journal of International Business Studies, 21, 1-22.

Goodwin, M., Duncan, S., \& Halford, S. (1993). Regulation theory, the local state, and the transition of urban politics. Environment and Planning D: Society and Space, 11(1), 6788.

Gómez-Mejía, L. R., Haynes, K. T., Núñez-Nickel, M., Jacobson, K. J., \& Moyano-Fuentes, J. (2007). Socioemotional wealth and business risks in family-controlled firms: Evidence from Spanish olive oil mills. Administrative Science Quarterly, 52(1), 106-137.

Gökarıksel, B., \& Secor, A. J. (2009). New transnational geographies of Islamism, capitalism and subjectivity: The veiling-fashion industry in Turkey. Area, 41(1), 6-18.

Guillén, M. F. (2000). Business groups in emerging economies: A resource-based view. Academy of Management Journal, 43(3), 362-380.

Guillén, M. F., \& Capron, L. (2016). State capacity, minority shareholder protections and stock market development. Administrative Science Quarterly, 61(1), 125-160.

Gujarati, D. (1995). Basic Econometrics. Singapore: McGraw-Hill.

Habib, M., \& Zurawicki, L. (2001). Country-level investment and the effect of corruptionsome empirical evidence. International Business Review, 10, 687-700.

Habib, M., \& Zurawicki, L. (2002). Corruption and foreign direct investment. Journal of International Business Studies, 33(2), 291-307. 
Hamilton, C. B., \& Winters, L. A. (1992). Opening up international trade with Eastern Europe. Economic Policy, 7(14), 77-116.

Hermalin, B. E., \& Weisbach, M. S. (1988). The determinants of board composition. Journal of Economics, 19(4), 589-606.

Hernández, V., \& Nieto, M. J. (2015). The effect of the magnitude and direction of institutional distance on the choice of international entry modes. Journal of World Business, 50(1), 122-132.

Hillman, A. J., Shropshire, C., \& Cannella, A. A. (2007). Organizational predictors of women on corporate boards. Academy of Management Journal, 50(4), 941-952.

Hitt, M. A., Hoskisson, R. E., \& Kim, H. (1997). International diversification: Effects of innovation and firm performance in product-diversified firms. Academy of Management Journal, 40(4), 767-798.

Hoskisson, R. E., \& Hitt, M. A. (1988). Strategic control systems and relative R\&D investment in large multiproduct firms. Strategic Management Journal, 9(6), 605-621.

Ilhan-Nas, T. (2012). Institutional distance influences on the multinational enterprises (MNES') ownership strategies of their affiliates operating in an emerging market. African Journal of Business Management, 6(20), 6276-6290.

Ilhan-Nas, T., Okan, T., Tatoglu, E., Demirbag, M., \& Glaister, K. W. (2018). The effects of ownership concentration and institutional distance on the foreign equity ownership strategy of Turkish MNEs. Journal of Business Research, https://doi.org/10.1016/j.jbusres.2018.02.006

Ionascu, D., Meyer, K. E., \& Estrin, S. (2004). Institutional distance and international business strategies in emerging economies, William Davidson Institute Working Paper Number 728, The University of Michigan Business School.

Jensen, M., \& Meckling, W. H. (1976). Theory of the firm: Managerial behavior, agency cost and ownership structure. Journal of Financial Economics, 3, 287-322.

Johansen, B., \& Schoar, A., 2006. The role of family in family firms. The Journal of Economic Perspectives, 20(2), 73-96. 
John, K., \& Senbet, L. W. (1998). Corporate governance and board effectiveness. Journal of Banking and Finance, 22(4), 371-403.

John, K., Litov, L., \& Yeung, B., 2008. Corporate governance and risk-taking. The Journal of Finance, 63(4), 1679-1728.

Johnson, J. L., Daily, C. M., \& Ellstrand, A. E. (1996). Boards of directors: A review and research agenda. Journal of Management, 22(3), 409-438.

Jones, G., \& Rose, M. B. (1993). Family capitalism. Business History, 35(4), 1-16.

Judge, W. (2012). Owner type as emerging area of governance research. Corporate Governance: An International Review, 20(3), 231-232.

Kaymak, T., \& Bektaş, E. (2008). East meets west? Board characteristics in an emerging market: Evidence from Turkish banks. Corporate Governance: An International Review, $16(6), 550-561$.

Kaynak, E., Demirbag, M., \& Tatoglu, E. (2007). Determinants of ownership-based entry mode choice of MNE's: Evidence from Mongolia. Management International Review, 47(4), 505-530.

Kennedy, P. (1999). A Guide to Econometrics. Massachusetts: Blackwell Publishers.

Killing, J. P. (1983). Strategies for Joint Venture Success. New York: Praeger.

Kim, K. A., Kitsabunnarat-Chatjuthamard, P., \& Nofsinger, J. R. (2007). Large shareholders, board independence, and minority shareholder rights: Evidence from Europe. Journal of Corporate Finance, 13(5), 859-880.

Klapper, L. F., \& Love, I., 2004. Corporate governance, investor protection, and performance in emerging markets. Journal of Corporate Finance, 10(5), 703-728.

Kogut, B., \& Sing, H. (1988). The effect of national culture on the choice of entry mode. Journal of International Business Studies, 19(3), 411-432.

Kolstad, I., \& Vilanger, E. (2008). Determinants of foreign direct investment in services. European Journal of Political Economy, 24(2), 518-533.

Kostova, T. (1999). Transnational transfer of strategic organizational practices: A contextual perspective. Academy of Management Review, 24(2), 308-324. 
Kraus, S., Kallmuenzer, A., Stieger, D., Peters, M., \& Calabrò, A. (2018). Entrepreneurial paths to family firm performance. Journal of Business Research, 88, 382-387.

Kula, V., \& Tatoglu, E. (2006). Board process attributes and company performance of familyowned businesses in Turkey. Corporate Governance, 6(5), 624-634.

La Porta, R., Lopez-de-Silanes, F., Shleifer, A., \& Vishny, R. W. (2000a). Agency problems and dividend policies around the world. The Journal of Finance, 55(1), 1-33.

La Porta, R., Lopez-de-Silanes, F., Shleifer, A., \& Vishny, R. W. (2000b). Investor protection and corporate governance. Journal of Financial Economics, 58(1), 3-27.

Lane, C., \& Wood, G. (2009). Capitalist diversity and diversity within capitalism. Economy and Society, 38(4), 531-551.

Larimo, J. (2003). Form of investment by Nordic firms in world markets. Journal of Business Research, 56(10), 791-803.

Lele, P. P., \& Siems, M. M. (2007). Shareholder protection: a leximetric approach. Journal of Corporate Law Studies, 7(1), 17-50.

Lien, Y-C., Piesse, J., Strange, R., \& Flatotchev, I. (2005). The role of corporate governance in FDI decisions: Evidence from Taiwan. International Business Review, 14, 739-763.

Lu, J., Xu, B., \& Liu, X. (2009). The effects of corporate governance and institutional environments on export behavior in emerging economies: Evidence from China. Management International Review, 49, 455-478.

Lu, J. W., \& Beamish, P. W. (2004). International diversification and firm performance: The S-curve hypothesis. Academy of Management Journal, 47(4), 598-609.

Luo, Y. (2004). An organizational perspective of corruption. Management and Organization Review, 1(1), 119-154.

Mak, Y. T., \& Li, Y. (2001). Determinants of corporate ownership and board structure: Evidence from Singapore. Journal of Corporate Finance, 7, 235-256.

Makino, S., \& Tsang, E. W. (2011). Historical ties and foreign direct investment: An exploratory study. Journal of International Business Studies, 42(4), 545-557.

Malhotra, S., \& Gaur, A. S. (2014). Spatial geography and control in foreign acquisitions. Journal of International Business Studies, 45(2), 191-210. 
McClean, E. J., Burris, E. R., \& Detert, J. R. (2013). When does voice lead to exit? It depends on leadership. Academy of Management Journal, 56(2), 525-548.

Meyer, K. E., Estrin, S., Bhaumik, S., \& Peng, M. W. (2009), Institutions, resources, and entry strategies in emerging economies. Strategic Management Journal, 30, 61-80.

Meyer, K. E., Ding, Y., Li, J., \& Zhang, H. (2014). Overcoming distrust: How state-owned enterprises adapt their foreign entries to institutional pressures abroad. Journal of International Business Studies, 45(8), 1005-1028.

Morck, R., \& Yeung, B. (2003). Agency problems in large family business groups. Entrepreneurship Theory and Practice, 27(4), 367-382.

Morgan, G., \& Kristensen, P. H. (2006). The contested space of multinationals: Varieties of institutionalism, varieties of capitalism. Human Relations, 59(11), 1467-1490.

Musteen, M, Datta, D. K., \& Herrmann, P. (2009). Ownership structure and CEO compensation: Implication for the choice of foreign market entry modes. Journal of International Business Studies, 40, 321-338.

North, D. C. (1987). Institutions, transaction costs and economic growth. Economic Inquiry, 25(3), 419-428.

North, D. C. (1990). Institutions, Institutional Change, and Economic Performance. Cambridge, Massachusetts: Harvard University Press.

Oetzel, J. M., Bettis, R. A., \& Zenner, M. (2001). Country risk measures: How risky are they? Journal of World Business, 36(2), 128-145.

Palepu, K. (1985). Diversification strategy, profit performance and the entropy measure. Strategic Management Journal, 6(3), 239-255.

Pan, Y. (2002). Equity ownership in international joint ventures: The impact of source country factors. Journal of International Business Studies, 33(2), 375-384.

Peng, M. W. (2003). Institutional transitions and strategic choices. Academy of Management Review, 28(2), 275-296.

Peng, M. W. (2004). Outside directors and firm performance during institutional transitions. Strategic Management Journal, 25, 453-471. 
Peng, M. W., Wang, D. Y. L., \& Jiang, Y. (2008). An institution based view of international business strategy: A focus on emerging economies, Journal of International Business Studies, 39, 920-936.

Quer, D., Claver, E., \& L. Rienda (2007). The impact of country risk and cultural distance on entry mode choice: An integrated approach. Cross Cultural Management: An International Journal, 14(1), 74-87.

Rhoades, D. L., \& Rechner, P. L. (2001). The role of ownership and corporate governance factors in international entry mode selection. The International Journal of Organizational Analysis, 9(4), 309-326.

Rugman, A. M. (2003). Politics and international investment. Journal of International Business Studies, 34(2), 223-225.

Sciascia, S., Mazzola, P., Astrachan, J. H., \& Pieper, T. M., 2012. The role of family ownership in international entrepreneurship: Exploring nonlinear effects. Small Business Economics, 38(1), 15-31.

Schulze, W. S., Lubatkin, M. H., Dino, R. N., \& Buchholtz, A. K. (2001). Agency relationships in family firms: Theory and evidence. Organization Science, 12(2), 99-116.

Schwens, C., Eiche, J., \& Kabst, R. (2011). The moderating impact of informal institutional distance and formal institutional risk on SME entry mode choice. Journal of Management Studies, 48(2), 330-351.

Scott, R. (2001). Institutions and Organizations. Thousand Oaks, CA: Sage Publication.

Selekler-Goksen, N., \& Karatas, A. (2008). Board structure and performance in an emerging economy: Turkey. International Business Governance and Ethics, 4(2), 132-147.

Selekler-Goksen, N., \& Yildirim-Oktem, O. (2009). Countervailing institutional forces: Corporate governance in Turkish family business groups. Journal of Management Governance, 13, 193-213.

Siems, M. (2008). Shareholder protection around the world ('Leximetric II'). Delaware Journal of Corporate Law, 33, 111-147.

Singh, D., \& Gaur, A. S. (2013). Governance structure, innovation and internationalization: Evidence from India. Journal of International Management, 19(3), 300-309. 
Slangen, A. H., \& Beugelsdijk, S. (2010). The impact of institutional hazards on foreign multinational activity: A contingency perspective. Journal of International Business Studies, 41(6), 980-995.

Stewart, A. (2003). Help one another, use one another: Toward an anthropology of family business. Entrepreneurship Theory and Practice, 27(4), 383-396.

Strange, R., Filatotchev, I., Buck, T., \& Wright, M. (2009). Corporate governance and international business. Management International Review, 49(4), 395-407.

Suehiro, A., \& Wailerdsak, N. (2004). Family business in Thailand: Its management, governance and future challenges, ASEAN Economic Bulletin, 21(1), 81-93.

Surdu, I., \& Mellahi, L. (2016). Theoretical foundations of equity based foreign market entry decisions: A review of the literature and recommendations for future research. International Business Review, 25(5), 1169-1184.

Tatoglu, E., \& Glaister, K. W. (1998). Western MNCs' FDI in Turkey: An analysis of location specific factors. Management International Review, 38(2), 133-159.

Tihanyi, L., Griffith, D. A., \& Russell, C. J. (2005). The effect of cultural distance on entry mode choice, international diversification, and MNE performance: A meta-analysis. Journal of International Business Studies, 36(3), 270-283.

Tihanyi, L., Johnson, R. A., Hoskisson, R. E., \& Hitt, M. A. (2003). Institutional ownership differences and international diversification: The effects of boards of directors and technological opportunity. Academy of Management Journal, 46(2), 195-211.

Toulan, O. N. (2002). The impact of market liberalization on vertical scope: The case of Argentina. Strategic Management Journal, 23(6), 551-560.

Usdiken, B., \& Yildirim-Oktem, O. (2008). Changes in the institutional environment and "nonexecutive" and "independent" directors on the boards of firms affiliated to large family business groups. Amme İdaresi Dergisi, 41(1), 43-71.

Voyer, P. A., \& Beamish, P. W. (2004). The effect of corruption on Japanese foreign direct investment. Journal of Business Ethics, 50(3), 211-224.

Wolf, C., \& Weinschrott, D. (1973). International transactions and regionalism: distinguishing" insiders" from" outsiders", The American Economic Review, 63(2), 52-60. 
Wood, G., \& Demirbag, M. (2012). Institutions and comparative business studies: Supranational and national regulation, in Wood, G.T. and Demirbag, M. (eds.) Handbook of Institutional Approaches to International Business, Cheltenham: Edward Elgar, 3-17.

Wood, G., \& Lane, C. (2012). Institutions, change and diversity, in Lane, C. and Wood, G. (eds.), Capitalist Diversity and Diversity within Capitalism. London: Routledge, 1-31.

Wood, G., Dibben, P., \& Ogden, S. (2014a). Comparative capitalism without capitalism, and production without workers: The limits and possibilities of contemporary institutional analysis. International Journal of Management Reviews, 16(4), 384-396.

Wood, G., Yin, S., Mazouz, K. \& Cheah, E.T. (2014b) Foreign direct investment from emerging markets to Africa: The HRM context. Human Resource Management, 53 (1),179-201.

World Economic Forum (2015). The Global Competitiveness Report 2015-2016, Geneva: World Economic Forum.

Wright, M., Filototchev, I., Hoskisson, R. E., \& Peng, M. W. (2005). Guest editors' introduction strategy research in emerging economies: Challenging the conventional wisdom. Journal of Management Studies, 42(1), 1-27.

Xu, D., \& Shenkar, O. (2002). Institutional distance and the multinational enterprise. Academy of Management Review, 27(4), 608-618.

Xu, D., Pan, Y., \& Beamish, P. W. (2004). The effect of regulative and normative distances on MNE ownership and expatriate strategies. Management International Review, 44(3), 285-307.

Yamak, S., \& Usdiken B. (2006). Economic liberalization and the antecedents of top management teams: Evidence from Turkish 'big' business. British Journal of Management, 17, 144-194.

Yildirim, O., \& Usdiken, B. (2007). Reconciling family-centric and professionalized governance: Boards of firms within family business groups. Academy of Management Best Papers Proceedings, Philadelphia, US.

Yildirim-Oktem, O., \& Usdiken, B. (2010). Contingencies versus external pressure: Professionalization in boards of firms affiliated to family business groups in lateindustrializing countries. British Journal of Management, 21(1), 115-130. 
Yiu, D., \& Makino, S. (2002). The choice between joint venture and wholly owned subsidiary: An institutional perspective. Organization Science, 13(6), 667-683.

Young, M. N., Ahlstrom, D., Bruton, G. D., and Chan, E. (2001). The resource dependence, service, and control functions of boards of directors in Hong Kong and Taiwanese firms. Asia Pacific Journal of Management, 18, 233-243.

Yurtoglu, B. (2000). Ownership, control and performance of Turkish listed firms. Empirica, 27, 193-222.

Yurtoglu, B. (2003). Corporate governance and implications for minority shareholders in Turkey. Turkish Economic Association, Discussion Paper 2003/7, http://tek.org.tr.

Zahra, S. A., \& Pearce, J. A. (1989). Boards of directors and corporate financial performance: A review and integrative model. Journal of Management, 15, 291-334.

Zahra, S. A. (2005). Entrepreneurial risk taking in family firms. Family Business Review, 18(1), 23-40.

Zahra, S. A. (2003). International expansion of US manufacturing family businesses: The effect of ownership and involvement. Journal of Business Venturing, 18(4), 495-512.

Zattoni, A., \& Cuomo, F. (2010). How independent, competent and incentivized should nonexecutive directors be? An empirical investigation of good governance codes. British Journal of Management, 21(1), 63-79.

Zeitner, M. (1998). Test Anxiety: The State of the Art. New York: Kluwer Academic Publishers.

Zhao, H., \& Zhu, G. (1998). Determinants of ownership preference of international joint ventures: New evidence from Chinese manufacturing industries. International Business Review, 7, 569-589. 


\section{Appendix A. Variable measurement}

\begin{tabular}{|c|c|c|c|}
\hline Variable & Measurement & Source & Related measurement previously used \\
\hline Dependent variable: Foreign equity ownership & $\begin{array}{l}\text { The proportion of equity shareholding of Turkish MNE on its affiliate } \\
\text { operating in host country. }\end{array}$ & $\begin{array}{l}\text { Public Disclosure Platform (http://www.kap.gov.tr) } \\
\text { and the firms' annual reports }\end{array}$ & --- \\
\hline \multicolumn{4}{|l|}{ Predictor variables: } \\
\hline $\begin{array}{l}\text { The ratio of independent directors } \\
\text { The ratio of inside directors } \\
\text { The ratio of family directors } \\
\text { The equity stake held by family directors }\end{array}$ & $\begin{array}{l}\text { The number of independent directors divided by the total number of board } \\
\text { directors } \\
\text { The number of inside directors divided by the total number of board directors } \\
\text { The number of family directors divided by the total number of board directors } \\
\text { The proportion of the equity stake held by family directors }\end{array}$ & $\begin{array}{l}\text { MNEs' Corporate Governance Principles Compliance } \\
\text { Reports (CGPC) } \\
\text { Firms' annual reports and audited financial tables } \\
\text { Audit financial tables }\end{array}$ & $\begin{array}{l}\text { Rhoades and Rechner (2001); Filatotchev et al. } \\
(2001,2008) \text {, Lien et al. (2005); Kaymak and Bektas } \\
\text { (2008); Selekler-Goksen and Karatas (2008); Lu et } \\
\text { al. (2009); Yildirim-Oktem and Usdiken (2010); } \\
\text { Filatotchev and Wright (2011); Demsetz and } \\
\text { Villagonga (2001). }\end{array}$ \\
\hline $\begin{array}{l}\text { Moderator variable: } \text { Institutional distance } \\
\text { (Regulative distance and normative distance) }\end{array}$ & $\begin{array}{l}\text { The institutional distance (by using eleven sub-items mentioned in regulative } \\
\text { and normative distance below) were computed using the following procedure } \\
\text { by Kogut and Singh }(1988) \text { : } \\
D=\sqrt{\sum_{i} \frac{\left(I_{i, h a s s}-I_{i, o r i g i n}\right)^{2}}{V_{i}}} \\
\text { where "Ii, host (Ii, origin) is the ith dimension (total } 11 \text { dimensions) of the } \\
\text { index for the host country (country of origin- Turkey) and Vi is the variance } \\
\text { of ith dimension" Standardized values for each sub-index were used since } \\
\text { scales are not the same across dimensions. } \\
\text { Regulative distance: six items (property rights, intellectual property rights } \\
\text { protection, judicial independence, burden of government regulation, } \\
\text { efficiency of legal framework and transparency of government policymaking) } \\
\text { were used for measuring regulative score. } \\
\text { Normative distance; five items (ethical behavior of firms, strength of auditing } \\
\text { and reporting standards, efficacy of corporate boards, quality of management } \\
\text { schools) were used for computing normative scores. }\end{array}$ & $\begin{array}{l}\text { The Global Competitiveness Report 2015-2016 } \\
\text { (WEF, 2015) published annually by World Economic } \\
\text { Forum (WEF) }\end{array}$ & $\begin{array}{l}\text { Xu et al. (2004); Ionascu et al. (2004); Demirbag et } \\
\text { al. (2007); Kaynak et al. (2007); Arslan and Larimo } \\
\text { (2010). Chao and Kumar (2010); Ilhan-Nas (2012). }\end{array}$ \\
\hline
\end{tabular}

\section{Control variables:}

schools) were used for computing normative scores.

Parent company level controls

Board size

International diversification

Unrelated product diversification
The total number of directors on the board

This variable was formulated as:

$$
\left[\frac{\text { Subidiary }(i)}{\operatorname{Subsidiary}(\text { Max })}+\frac{\text { Country }(i)}{\text { Contry }(\text { Max })}\right] / 2
$$

where affiliate ( $i$ ) is the MNE's total number of foreign affiliates, affiliate $(\max )$ is maximum number of foreign subsidiaries in all sample, country $(i)$ is the numbers of countries in which the MNE invest, country (max) is the maximum number of FDI countries in all sample.

This variable was formulated as:

$$
D U=\sum_{j=1}^{M} P^{J} \ln \left(1 / P^{J}\right)
$$

where $P^{J}$ is the share of the $j$ th group sales in the total sales of the firm and DU is unrelated diversification" (Palepu, 1985:252-253).
MNEs' CGPC reports and firms' annual reports Public Disclosure Platform (http://www.kap.gov.tr) and the firms' annual reports.

Lien et al. (2005); Kaymak and Bektas (2008) Delios and Beamish (1999b); Lu and Beamish (2004); David et al. (2010).

Public Disclosure Platform (http://www.kap.gov.tr), firm' financial statements, and SIC code:

http:/www oshagov/pls/imis/sicsearch htm
Palepu (1985); Hitt et al. (1997); Delios and Beamish (1999b); Carpenter and Fredrickson (2001); Hillman et al. (2007); Bouquet et al. (2009); David et al. (2010). 


\section{Appendix A. (Continued)}

\begin{tabular}{|c|c|c|c|}
\hline Variable & Measurement & Source & Related measurement previously used \\
\hline \multicolumn{4}{|l|}{ Affiliate level controls } \\
\hline The size of the affiliate & The contributed capital of the affiliate in Turkish Lira. & $\begin{array}{l}\text { Annual reports, auditing financial statements and general } \\
\text { information, and notifications released in PDP. }\end{array}$ & $\begin{array}{l}\text { 1Luo (2004); Kaynak et al. (2007); Demirbag et al. } \\
\text { (2009). }\end{array}$ \\
\hline Industry & $\begin{array}{l}\text { The subsidiaries were classified into following industries which include, } \\
\text { agriculture, forestry and fishing, mining, construction, manufacturing, } \\
\text { transportation, communication, electric, gas and sanitary services, wholesale and } \\
\text { retail trade, finance, insurance and real estate and services. Then, three broad } \\
\text { industry categories were created: manufacturing, service and tertiary industries. }\end{array}$ & SIC Divisions (www.osha.gov) & $\begin{array}{l}\text { Demirbag et al. (2007); Demirbag et al. (2008); } \\
\text { Demirbag et al. (2009); Ilhan-Nas (2012). }\end{array}$ \\
\hline \multicolumn{4}{|l|}{ Host country level controls } \\
\hline Protection of minority shareholder rights & $\begin{array}{l}\text { The protection of minority shareholder rights is computed by the sum of the scores } \\
\text { for each of the ten legal provisions (powers of the general meeting for de facto } \\
\text { changes, agenda-setting power, anticipation of shareholder decision facilitated, } \\
\text { prohibition of multiple voting rights, independent board members, feasibility of } \\
\text { directors' dismissal, private enforcement of directors' duties, shareholder action } \\
\text { against resolutions of the general meeting, mandatory bid, disclosure of major share } \\
\text { ownership), and it ranges from } 0 \text { to } 10 \text {. }\end{array}$ & $\begin{array}{l}\text { Guillén - Capron Shareholder Protections Index } \\
\text { https://whartonmgmt.wufoo.com/forms/guillencapron- } \\
\underline{\text { shareholder-protections-index/ }}\end{array}$ & $\begin{array}{l}\text { Lele and Siems (2007); Siems (2008); Guillén and } \\
\text { Capron (2016). }\end{array}$ \\
\hline Cultural distance & $\begin{array}{l}\text { Using Hofstede's (1980) four cultural dimensions, the cultural distance was } \\
\text { measured was measured based on the following formula (Kogut and Singh, 1988): } \\
C D=\sqrt{\sum_{i} \frac{\left(I_{i, \text { host }}-I_{i, o r i g i n}\right)^{2}}{V_{i}}} \\
\text { where "Ii host (Ii origin) is the ith dimension (Power distance, individualism, } \\
\text { masculinity and uncertainty avoidance) of the index for the host country (country of } \\
\text { origin-Turkey) and Vi is the variance of ith dimension. }\end{array}$ & $\begin{array}{l}\text { Hofstede's cultural dimensions published by Hofstede } \\
\text { Insights https://www.hofstede-insights.com/country- } \\
\text { comparison/ }\end{array}$ & $\begin{array}{l}\text { Berry et al. (2010); Makino and Tsang (2011); } \\
\text { Dellestrand and Kappen (2012); Campbell and Eden } \\
\text { (2012). }\end{array}$ \\
\hline Geographic distance & $\begin{array}{l}\text { Geographic distance as the actual distance in kilometers between capital cities of } \\
\text { the home and host countries. }\end{array}$ & http://www.harita.gen.tr/mesafe-hesaplama/ & $\begin{array}{l}\text { Wolf and Weinschrott (1973); Hamilton and Winters } \\
\text { (1992); Fratianni and Oh (2009); Slangen and } \\
\text { Beugelsdijk (2010); Malhotra and Gaur (2014); } \\
\text { Contractor et al. (2016). }\end{array}$ \\
\hline Linguistic distance & $\begin{array}{l}\text { This study follows the same path in operationalizing the linguistic distance by } \\
\text { adopting the dendrogram developed by Chen et al. (1995). They constructed this } \\
\text { dendrogram by using the UPMGA method based on unequal branch length } \\
\text { linguistic distances. The dendrogram's tree includes } 130 \text { localities around the world, } \\
\text { which covers all languages used by investors in the database used for this study. }\end{array}$ & Chen et al. (1995) & Chen et al. (1995); Demirbag et al. (2009) \\
\hline Corruption distance & $\begin{array}{l}\text { This distance was measured through the following procedure developed by (Kogut } \\
\text { and Singh, } 1988) \text { : } \\
D=\sqrt{\sum_{i} \frac{\left(I_{i, \text { hoss }}-I_{i, o r i g i n}\right)^{2}}{V_{i}}} \\
\text { where "I } \mathrm{I}_{\mathrm{i}, \text { host }}\left(\mathrm{I}_{\mathrm{i}, \text { origin }}\right) \text { is the } i \text { th dimension of the index for the host country (country } \\
\text { of orign- Turkey) and } V_{i} \text { is the variance of } i \text { th dimension". Standardized values for } \\
\text { each sub-index were used since scales are not the same across dimensions. }\end{array}$ & $\begin{array}{l}\text { Transparency International's Corruption Perception } \\
\text { Index (CPI) scores (http://www. } \\
\text { transparency.org/policy_research/ } \\
\text { surveys_indices/cpi/2009/cpi_2009_table) }\end{array}$ & $\begin{array}{l}\text { Habib and Zurawicki (2001); Habib and Zurawicki } \\
\text { (2002); Voyer and Beamish (2004); Demirbag et al. } \\
\text { (2007). }\end{array}$ \\
\hline Country risk & $\begin{array}{l}\text { The country risk scores of the PRS group are based on a composite risk rating: } \\
C P F E R(\text { country } X)=0.5(P R+F R+E R) \text { where CPFER is the composite } \\
\text { political, financial and economic risk ratings, PR is the total political risk indicators, } \\
\text { FR is total financial risk indicators, ER is total economic risk indicators. }\end{array}$ & $\begin{array}{l}\text { International Country Risk Guide (ICRG) published by } \\
\text { The Political Risk Services (PRS) Group } \\
\end{array}$ & Oetzel et al. (2001); Kolstad and Vilanger (2008). \\
\hline Emerging market & The value of 0 denotes if the host country is an emerging market or 0 otherwise. & IMF country classification & Demirbag et al. (2007) \\
\hline
\end{tabular}


Figure 2A. Interaction between the proportion of inside directors and institutional distance

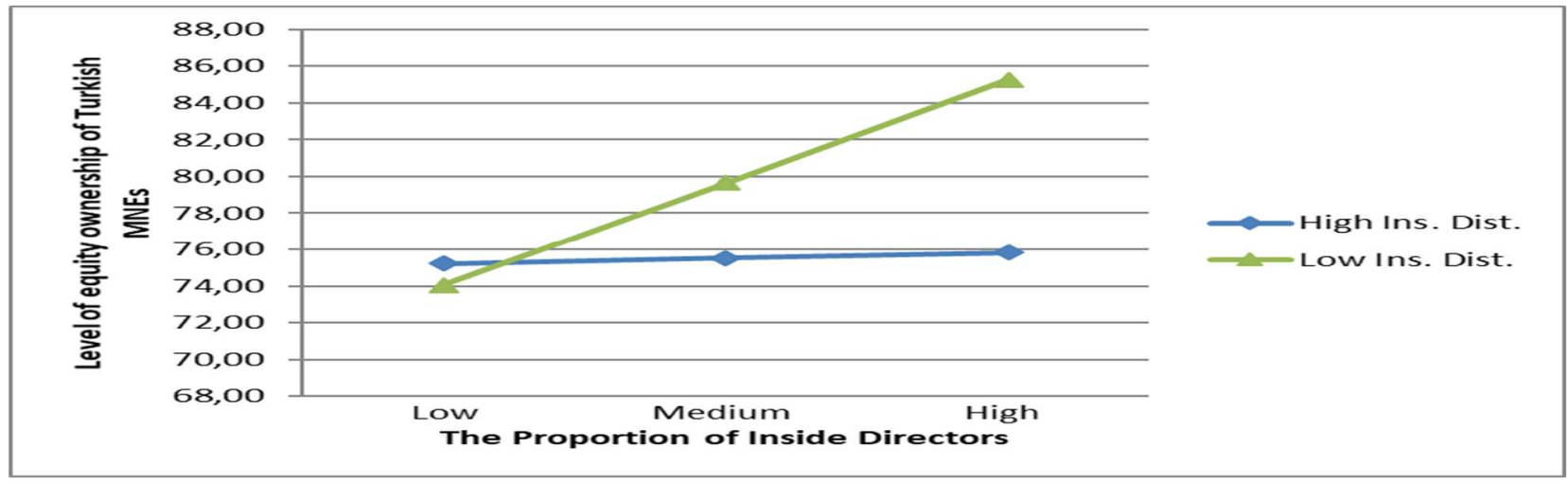

Figure 2B. Interaction between the proportion of independent directors and institutional distance

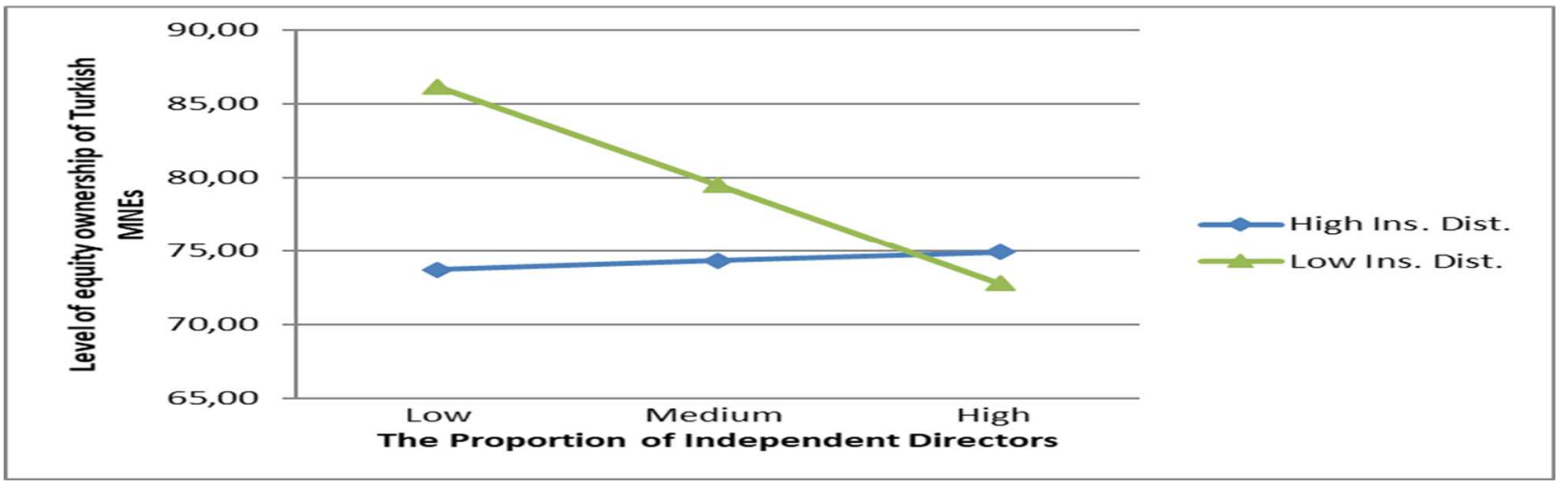

Figure 2C. Interaction between the proportion of family members and institutional distance

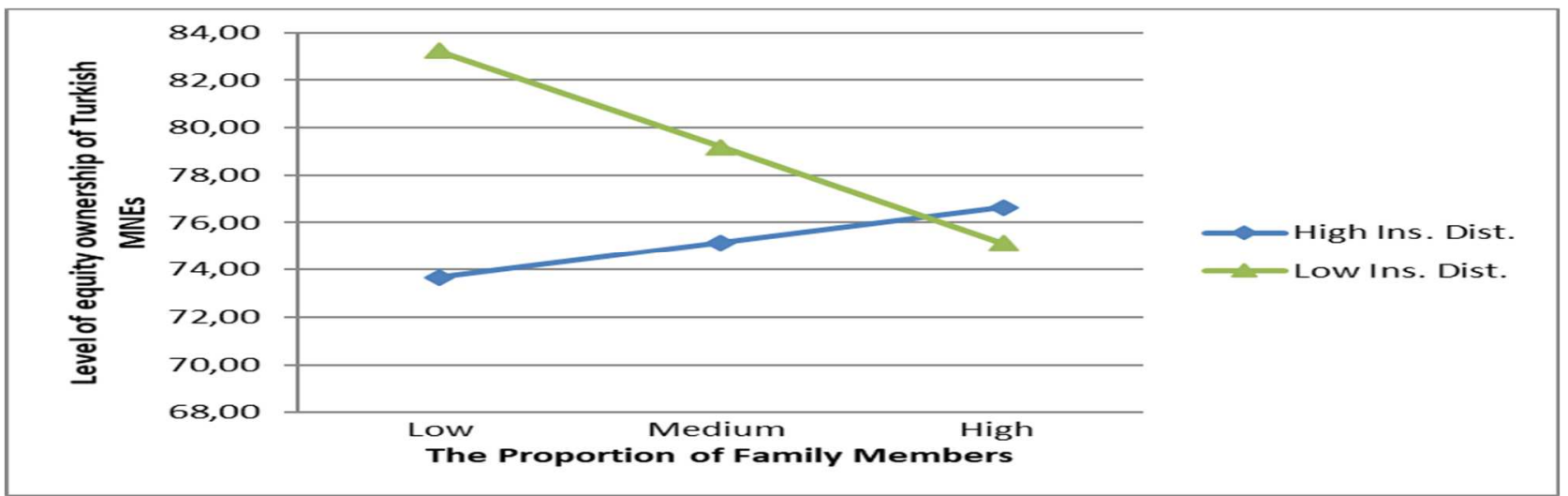

Figure 2D. Interaction between the proportion of equity stake held by family members and institutional distance

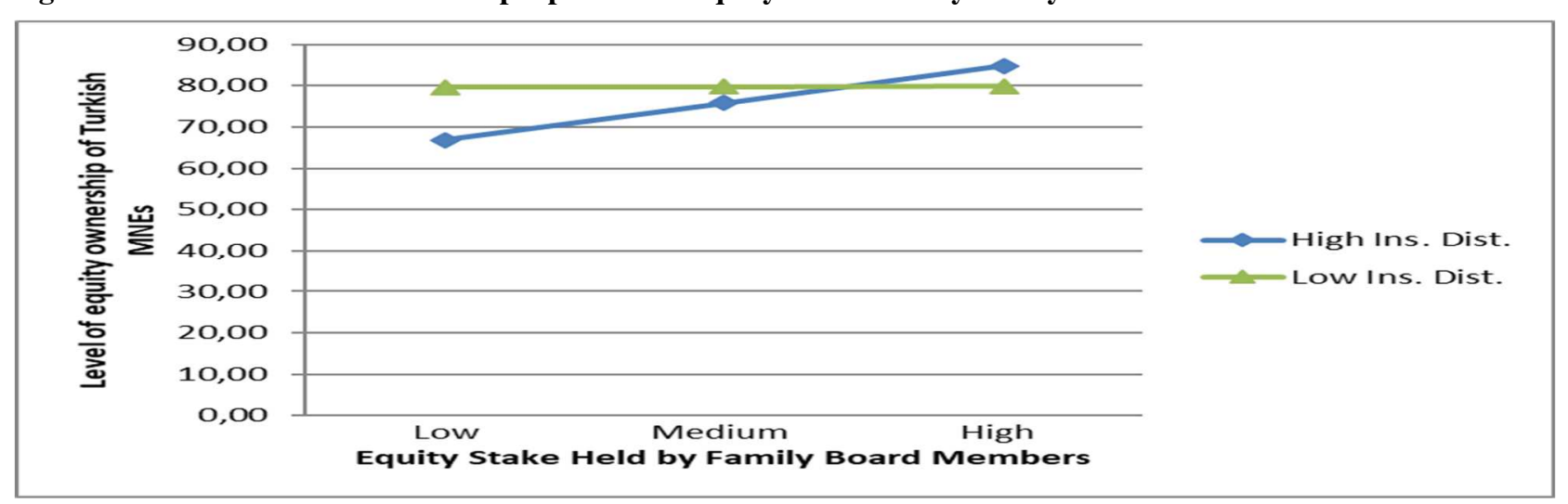


Table 1. Descriptive statistics and correlation matrix

\begin{tabular}{|c|c|c|c|c|c|c|c|c|c|c|c|c|c|c|c|c|c|c|c|c|c|}
\hline Variables & Mean & SD & 1 & 2 & 3 & 4 & 5 & 6 & 7 & 8 & 9 & 10 & 11 & 12 & 13 & 14 & 15 & 16 & 17 & 18 & 19 \\
\hline 1. Foreign equity ownership & 78.33 & 27.64 & 1 & & & & & & & & & & & & & & & & & & \\
\hline 2. Board size & 8.71 & 2.41 & $-.37^{*}$ & 1 & & & & & & & & & & & & & & & & & \\
\hline 3. Ratio of inside directors & 0.15 & 0.16 & .11 & $-.18^{*}$ & 1 & & & & & & & & & & & & & & & & \\
\hline 4. Ratio of independent directors & 0.11 & 0.14 & $-.18^{*}$ & .15 & -.03 & 1 & & & & & & & & & & & & & & & \\
\hline 5. Ratio of family directors & 0.21 & 0.20 & -.07 & $.32^{*}$ & -.05 & -.05 & 1 & & & & & & & & & & & & & & \\
\hline $\begin{array}{l}\text { 6. Ratio of equity stake held by } \\
\text { family directors }\end{array}$ & 10.53 & 12.76 & -.05 & $.28^{*}$ & .09 & $.31^{*}$ & $.49^{*}$ & 1 & & & & & & & & & & & & & \\
\hline 7. International diversification & 0.44 & 0.35 & $-.30^{*}$ & $.72^{*}$ & $-.28^{*}$ & .06 & $.29^{*}$ & .14 & 1 & & & & & & & & & & & & \\
\hline 8. Unrelated product diversification & 0.32 & 0.47 & $-.38^{*}$ & $.51^{*}$ & .13 & $.32^{*}$ & .10 & $.35^{*}$ & $.39^{*}$ & 1 & & & & & & & & & & & \\
\hline 9. Affiliate size (million) & 40.99 & 120.81 & -.09 & -.03 & -.05 & .08 & .00 & -.09 & -.05 & -.09 & 1 & & & & & & & & & & \\
\hline 10. Manufacturing industry & 0.32 & 0.47 & .10 & $-.26^{*}$ & .12 & .09 & $-.31^{*}$ & -.12 & $-.23^{*}$ & $-.17^{*}$ & .00 & 1 & & & & & & & & & \\
\hline 11. Tertiary industry & 0.36 & 0.48 & -.09 & $.12^{*}$ & -.05 & .10 & .09 & $.14^{*}$ & .02 & .15 & $.19^{*}$ & $-.51^{*}$ & 1 & & & & & & & & \\
\hline 12. Minority shareholder protection index & 6.39 & 1.13 & .06 & -.02 & .03 & -.12 & -.05 & .04 & .01 & -.01 & -.08 & $.18^{*}$ & $-.25^{*}$ & 1 & & & & & & & \\
\hline 13. Cultural distance & 1.73 & 0.72 & .03 & -.04 & .10 & .14 & -.02 & .05 & -.04 & .07 & .08 & $-.26^{*}$ & $.34^{*}$ & -.09 & 1 & & & & & & \\
\hline 14. Geographical distance (thousand) & 3.56 & 2.20 & .03 & -.08 & .10 & $.27^{*}$ & -.06 & .06 & -.08 & -.02 & -.02 & .07 & -.05 & -.10 & $.21^{*}$ & 1 & & & & & \\
\hline 15. Linguistic distance & 17.19 & 8.36 & -.03 & .02 & .10 & .13 & -.04 & -.07 & .07 & -.01 & -.04 & .09 & $-.18^{*}$ & -.10 & -.12 & $.54^{*}$ & 1 & & & & \\
\hline 16. Corruption distance & 1.13 & 0.55 & -.01 & -.02 & .00 & .03 & -.03 & -.03 & -.04 & .01 & .1 & $-.26^{*}$ & $.44^{*}$ & $-.22^{*}$ & $.71^{*}$ & -.08 & $-.25^{*}$ & 1 & & & \\
\hline 17. Country risk & 74.24 & 7.07 & -.08 & .14 & .07 & .14 & .06 & -.02 & .13 & $.16^{*}$ & .00 & $-.34^{*}$ & $.32^{*}$ & $-.30^{*}$ & $.67^{*}$ & .02 & .00 & $.68^{*}$ & 1 & & \\
\hline 18. Emerging market & 0.41 & 0.49 & .07 & -.07 & -.07 & -.12 & -.03 & .01 & -.06 & -.14 & -.02 & $.33^{*}$ & $-.30^{*}$ & $.24^{*}$ & $-.74^{*}$ & .02 & $.25^{*}$ & $-.63^{*}$ & $-.80^{*}$ & 1 & \\
\hline 19. Institutional distance & 4.42 & 2.02 & -.05 & .04 & .05 & .14 & .03 & -.01 & .02 & .09 & .06 & $-.34^{*}$ & $.40^{*}$ & $-.38^{*}$ & $.78^{*}$ & .02 & -.15 & $.86^{*}$ & $.89^{*}$ & $-.85^{*}$ & 1 \\
\hline
\end{tabular}

$* p<0.01$. 
Table 2. The results of OLS and Tobit regression models

\begin{tabular}{|c|c|c|c|c|c|c|c|c|c|c|c|c|c|c|c|c|c|c|}
\hline \multirow{4}{*}{ Variables $^{\mathrm{a}}$} & \multicolumn{18}{|c|}{ Dependent variable: Foreign equity ownership (\%) } \\
\hline & \multicolumn{10}{|c|}{ Main effects } & \multicolumn{8}{|c|}{ Interactive effects } \\
\hline & \multicolumn{2}{|c|}{ Model 1} & \multicolumn{2}{|c|}{ Model 2} & \multicolumn{2}{|c|}{ Model 3} & \multicolumn{2}{|c|}{ Model 4} & \multicolumn{2}{|c|}{ Model 5} & \multicolumn{2}{|c|}{ Model 6} & \multicolumn{2}{|c|}{ Model 7} & \multicolumn{2}{|c|}{ Model 8} & \multicolumn{2}{|c|}{ Model 9} \\
\hline & OLS & TOBIT & OLS & TOBIT & OLS & TOBIT & OLS & TOBIT & OLS & TOBIT & OLS & TOBIT & OLS & TOBIT & OLS & TOBIT & OLS & TOBIT \\
\hline \multicolumn{19}{|l|}{ Independent variables } \\
\hline Ratio of inside directors & 5.31 & 5.44 & 17.14" & $17.43^{*}$ & $16.87^{*}$ & $17.21^{*}$ & $16.86^{*}$ & $17.25^{*}$ & $16.75^{*}$ & $17.08^{*}$ & $18.05^{*}$ & $18.39^{*}$ & 14.60 & 14.93 & $17.23^{*}$ & $17.57^{*}$ & 15.77 & 16.09 \\
\hline Ratio of independent directors & $-31.59^{* * *}$ & $-31.49^{* *}$ & $-20.68^{*}$ & $-20.51^{*}$ & -17.35 & -17.13 & -16.61 & -16.19 & -16.80 & -16.49 & -15.14 & -14.82 & -21.68 & -22.36 & -15.66 & -15.33 & -15.11 & -14.81 \\
\hline Ratio of family directors & -1.15 & -1.30 & -8.14 & -8.40 & -7.43 & -7.80 & -6.36 & -6.69 & -6.09 & -6.42 & -7.81 & -8.16 & -6.54 & -6.86 & -6.48 & -6.82 & -3.59 & -3.91 \\
\hline $\begin{array}{l}\text { Ratio of equity stake held by family directors } \\
\text { Parent company level controls }\end{array}$ & -0.23 & -0.23 & -0.38 & -0.39 & -0.35 & -0.36 & -0.31 & -0.31 & -0.32 & -0.33 & -0.34 & -0.34 & -0.35 & -0.36 & -0.35 & -0.36 & -0.36 & -0.36 \\
\hline Board size & & & $-3.01^{*}$ & $-3.04^{*}$ & $-2.91^{*}$ & $-2.94^{*}$ & $-2.78^{*}$ & $-2.81^{*}$ & $-2.77^{*}$ & $-2.81^{*}$ & $-2.63^{*}$ & $-2.67^{*}$ & $-2.77^{*}$ & $-2.80^{*}$ & $-2.76^{*}$ & $-2.79^{*}$ & $-3.00^{*}$ & $-3.04^{*}$ \\
\hline International diversification & & & 2.64 & 2.82 & 2.18 & 2.36 & 2.14 & 2.33 & 2.13 & 2.31 & 2.02 & 2.19 & 2.64 & 2.81 & 1.60 & 1.77 & 2.54 & 2.71 \\
\hline $\begin{array}{l}\text { Unrelated product diversification } \\
\text { Affiliate level controls }\end{array}$ & & & $-18.46^{* * *}$ & $-18.56^{* *}$ & $-19.11^{* *}$ & $-19.23^{* *}$ & $-19.07^{* *}$ & $-19.19^{* * *}$ & $-19.17^{* * *}$ & $-19.30^{* * *}$ & $-19.66^{* *}$ & $-19.80^{* *}$ & $-20.15^{* *}$ & $-20.28^{* * *}$ & $-19.63^{* *}$ & $-19.77^{* *}$ & $-20.95^{* *}$ & $-21.07^{* * *}$ \\
\hline Affiliate size (million) & & & & & $-0.02^{*}$ & $-0.02^{*}$ & $-0.02^{*}$ & $-0.02^{*}$ & $-0.02^{*}$ & $-0.02^{*}$ & $-0.02^{*}$ & $-0.02^{*}$ & $-0.02^{*}$ & $-0.02^{*}$ & $-0.02^{*}$ & $-0.02^{*}$ & $-0.02^{*}$ & $-0.02^{*}$ \\
\hline Manufacturing industry & & & & & -0.84 & -0.99 & -0.91 & -1.12 & -0.67 & -0.83 & -1.15 & -1.32 & -0.95 & -1.11 & -1.39 & -1.56 & -1.27 & -1.43 \\
\hline \multicolumn{19}{|l|}{ Host country level controls } \\
\hline Minority shareholder protection index & & & & & & & 0.26 & 0.28 & 0.16 & 0.18 & 0.30 & 0.33 & -0.48 & -0.46 & 0.38 & 0.41 & 0.20 & 0.22 \\
\hline Cultural distance & & & & & & & 4.68 & 4.88 & 3.66 & 3.77 & 3.40 & 3.51 & 5.08 & 5.19 & 3.49 & 3.60 & 3.70 & 3.81 \\
\hline Geographical distance (thousand) & & & & & & & 0.00 & 0.00 & 0.00 & 0.00 & 0.00 & 0.00 & 0.00 & 0.00 & 0.00 & 0.00 & 0.00 & 0.00 \\
\hline Linguistic distance & & & & & & & -0.18 & -0.18 & -0.09 & -0.09 & -0.08 & -0.08 & -0.02 & -0.02 & -0.09 & -0.09 & -0.09 & -0.09 \\
\hline Corruption distance & & & & & & & -2.42 & -2.41 & & & & & & & & & & \\
\hline Country risk & & & & & & & 0.19 & 0.19 & & & & & & & & & & \\
\hline Emerging market & & & & & & & 6.51 & 6.90 & & & & & & & & & & \\
\hline \multicolumn{19}{|l|}{ Moderator variable } \\
\hline $\begin{array}{l}\text { Institutional distance } \\
\text { Interactive effects }\end{array}$ & & & & & & & & & -1.01 & -1.04 & -1.02 & -1.05 & -1.28 & -1.31 & -1.00 & -1.03 & -0.98 & -1.01 \\
\hline Institutional distance X Ratio of inside directors & & & & & & & & & & & $-8.01^{*}$ & $-8.09^{*}$ & & & & & & \\
\hline $\begin{array}{l}\text { Institutional distance X Ratio of independent } \\
\text { directors }\end{array}$ & & & & & & & & & & & & & $12.82^{*}$ & $12.82^{*}$ & & & & \\
\hline Institutional distance X Ratio of family directors & & & & & & & & & & & & & & & $6.96^{*}$ & $7.01^{*}$ & & \\
\hline $\begin{array}{l}\text { Institutional distance X Ratio of equity stake held } \\
\text { by family directors }\end{array}$ & & & & & & & & & & & & & & & & & $0.17^{* *}$ & $0.17^{* *}$ \\
\hline Constant & $78.33^{* * *}$ & $78.30^{* *}$ & $81.92^{* *}$ & $81.76^{* *}$ & $83.77^{* * *}$ & $83.66^{* *}$ & $63.15^{*}$ & $62.06^{*}$ & $77.71^{* * *}$ & $77.28^{* *}$ & $77.59^{* *}$ & $77.15^{\text {** }}$ & $76.90^{* * *}$ & $76.48^{* *}$ & $77.17^{* * *}$ & $76.72^{* *}$ & $77.80^{* * *}$ & $77.37^{* * *}$ \\
\hline$F$ & $10.44^{* *}$ & & $10.83^{* * *}$ & & $7.88^{* *}$ & & $4.69^{* * *}$ & & $5.29^{* * *}$ & & $5.16^{* *}$ & & $5.27^{* * *}$ & & $5.19^{\text {*** }}$ & & $5.57^{* *}$ & \\
\hline Adjusted $R^{2}$ & 0.15 & & 0.20 & & 0.20 & & 0.19 & & 0.19 & & 0.20 & & 0.20 & & 0.20 & & 0.21 & \\
\hline$L R \chi^{2}$ & & $48.28^{* *}$ & & $68.33^{* *}$ & & $71.35^{* * *}$ & & $74.08^{* *}$ & & $73.08^{* *}$ & & $75.95^{* *}$ & & $77.37^{* *}$ & & $76.42^{* *}$ & & $81.20^{* * *}$ \\
\hline
\end{tabular}

